Cochrane Database of Systematic Reviews

\title{
Interventions for congenital talipes equinovarus (clubfoot) (Review)
}

Gray K, Pacey V, Gibbons P, Little D, Burns J

Gray K, Pacey V, Gibbons P, Little D, Burns J.

Interventions for congenital talipes equinovarus (clubfoot).

Cochrane Database of Systematic Reviews 2014, Issue 8. Art. No.: CD008602.

DOI: 10.1002/14651858.CD008602.pub3.

www.cochranelibrary.com 
TABLE OF CONTENTS

HEADER 1

ABSTRACT

PLAIN LANGUAGE SUMMARY

SUMMARY OF FINDINGS

BACKGROUND

OBJECTIVES

METHODS

RESULTS

Figure 1.

Figure 2.

Figure 3.

Figure 4.

DISCUSSION

AUTHORS' CONCLUSIONS

ACKNOWLEDGEMENTS

REFERENCES

CHARACTERISTICS OF STUDIES

DATA AND ANALYSES

Analysis 1.1. Comparison 1 Kite versus Ponseti technique for treatment of initial CTEV, Outcome 1 Pirani score at 10 weeks. ...

Analysis 2.1. Comparison 2 Ponseti versus traditional treatment (plaster casting and surgery) for treatment of initial CTEV, Outcome 1 Pirani score at end of serial plaster casting.

Analysis 3.1. Comparison 3 Standard Ponseti technique versus an accelerated Ponseti technique, Outcome 1 Pirani score at the end of serial plaster casting.

ADDITIONAL TABLES

APPENDICES

WHAT'S NEW

CONTRIBUTIONS OF AUTHORS

DECLARATIONS OF INTEREST

SOURCES OF SUPPORT

DIFFERENCES BETWEEN PROTOCOL AND REVIEW

INDEX TERMS

1

2

3

7

8

8

10

11

14

15

16

16

18

19

20

24

45

45

46 
[Intervention Review]

\section{Interventions for congenital talipes equinovarus (clubfoot)}

Kelly Gray ${ }^{1}$, Verity Pacey ${ }^{1}$, Paul Gibbons ${ }^{2}$, David Little², Joshua Burns ${ }^{3}$

1Department of Physiotherapy, The Children's Hospital at Westmead, Westmead, Australia. 2Department of Orthopaedic Surgery, The Children's Hospital at Westmead, Westmead, Australia. ${ }^{3}$ Faculty of Health Sciences, The University of Sydney, and Institute for Neuroscience and Muscle Research, The Children's Hospital at Westmead, Westmead, Australia

Contact address: Kelly Gray, Department of Physiotherapy, The Children's Hospital at Westmead, Locked Bag 4001, Westmead, New South Wales, 2145, Australia. kellye@chw.edu.au.

Editorial group: Cochrane Neuromuscular Group.

Publication status and date: New search for studies and content updated (no change to conclusions), published in Issue 8, 2014.

Citation: Gray K, Pacey V, Gibbons P, Little D, Burns J. Interventions for congenital talipes equinovarus (clubfoot). Cochrane Database of Systematic Reviews 2014, Issue 8. Art. No.: CD008602. DOI: 10.1002/14651858.CD008602.pub3.

Copyright @ 2014 The Cochrane Collaboration. Published by John Wiley \& Sons, Ltd.

\section{A B S T R A C T}

\section{Background}

Congenital talipes equinovarus (CTEV), which is also known as clubfoot, is a common congenital orthopaedic condition characterised by an excessively turned in foot (equinovarus) and high medial longitudinal arch (cavus). If left untreated it can result in long-term disability, deformity and pain. Interventions can be conservative (such as splinting or stretching) or surgical. The review was first published in 2012 and we reviewed new searches in 2013 (update published 2014).

\section{Objectives}

To evaluate the effectiveness of interventions for CTEV.

\section{Search methods}

On 29 April 2013, we searched CENTRAL (2013, Issue 3 in The Cochrane Library), MEDLINE (January 1966 to April 2013), EMBASE (January 1980 to April 2013), CINAHL Plus (January 1937 to April 2013), AMED (1985 to April 2013), and the Physiotherapy Evidence Database (PEDro to April 2013). We also searched for ongoing trials in the WHO International Clinical Trials Registry Platform (2006 to July 2013 ) and ClinicalTrials.gov (to November 2013). We checked the references of included studies. We searched NHSEED, DARE and HTA for information for inclusion in the Discussion.

\section{Selection criteria}

Randomised controlled trials (RCTs) and quasi-RCTs evaluating interventions for CTEV. Participants were people of all ages with CTEV of either one or both feet.

\section{Data collection and analysis}

Two authors independently assessed risk of bias in included trials and extracted the data. We contacted authors of included trials for missing information. We collected adverse event information from trials when it was available.

\section{Main results}

We identified 14 trials in which there were 607 participants; one of the trials was newly included at this 2014 update. The use of different outcome measures prevented pooling of data for meta-analysis even when interventions and participants were comparable. All trials displayed bias in four or more areas. One trial reported on the primary outcome of function, though raw data were not available to be analysed. We were able to analyse data on foot alignment (Pirani score), a secondary outcome, from three trials. Two of the trials involved participants at initial presentation. One reported that the Ponseti technique significantly improved foot alignment compared to the Kite technique. After 10 weeks of serial casting, the average total Pirani score of the Ponseti group was 1.15 (95\% confidence interval (Cl) 0.98 to 
1.32) lower than that of the Kite group. The second trial found the Ponseti technique to be superior to a traditional technique, with average total Pirani scores of the Ponseti participants 1.50 lower $(95 \% \mathrm{Cl} 0.72$ to 2.28$)$ after serial casting and Achilles tenotomy. A trial in which the type of presentation was not reported found no difference between an accelerated Ponseti or standard Ponseti treatment. At the end of serial casting, the average total Pirani scores in the standard group were 0.31 lower $(95 \% \mathrm{Cl}-0.40$ to 1.02$)$ than the accelerated group. Two trials in initial cases found relapse following Ponseti treatment was more likely to be corrected with further serial casting compared to the Kite groups which more often required major surgery (risk difference $25 \%$ and $50 \%$ ). There is a lack of evidence for different plaster casting products, the addition of botulinum toxin A during the Ponseti technique, different types of major foot surgery, continuous passive motion treatment following major foot surgery, or treatment of relapsed or neglected cases of CTEV. Most trials did not report on adverse events. In trials evaluating serial casting techniques, adverse events included cast slippage (needing replacement), plaster sores (pressure areas) and skin irritation. Adverse events following surgical procedures included infection and the need for skin grafting.

\section{Authors' conclusions}

From the limited evidence available, the Ponseti technique produced significantly better short-term foot alignment compared to the Kite technique and compared to a traditional technique. The quality of this evidence was low to very low. An accelerated Ponseti technique may be as effective as a standard technique, according to moderate quality evidence. Relapse following the Kite technique more often led to major surgery compared to relapse following the Ponseti technique. We could draw no conclusions from other included trials because of the limited use of validated outcome measures and lack of available raw data. Future randomised controlled trials should address these issues.

\section{PLAIN LANGUAGE SUMMARY}

\section{Interventions for congenital talipes equinovarus (clubfoot)}

\section{Review question}

The purpose of this review was to assess treatments for congenital talipes equinovarus (clubfoot).

\section{Background}

Clubfoot is a condition, present at birth, in which the foot is in an inturned position. There is no known cause. Different treatments might be effective at different stages: at birth (initial presentation); when initial treatment does not work (resistant presentation); when the initial treatment works but the clubfoot returns (relapse/recurrent presentation); and when there has been no early treatment (neglected presentation). Treatment aims to put the foot back into a normal position and be pain-free throughout life.

Treatment can be non-surgical, surgical or both. Non-surgical treatment (for example plaster casting or stretches) gently stretch the foot into a normal position. Surgery may involve the muscles, tendons, ligaments or joints.

\section{Study characteristics}

From our searches we found 14 trials with 607 participants. All trials had problems of design or conduct that might have affected the results. Treatments were studied at birth (eight trials, 326 participants), during relapse (four trials, 181 participants) or at an unknown time (two trials, 100 participants).

\section{Results and quality of the evidence}

Our main measure of the success of treatment was function (how well the foot worked in everyday life). Only one trial reported on function; however, data were not available to re-analyse. We analysed data from three trials. When treated at birth, foot position was better after Ponseti plaster casting than after Kite plaster casting. The quality of this evidence was low. When treated at birth, foot position was better after Ponseti plaster casting than after a traditional technique (another type of plaster casting). The quality of this evidence was very low. One trial found Ponseti plaster casting three times per week to be as good as weekly Ponseti casting. This trial did not state at which stage the treatment was done. The quality of this evidence was moderate. Relapse following Kite technique more often required major surgery than relapse following the Ponseti technique. Data were not available to assess the results for adding botulinum toxin A to the Ponseti treatment, using different types of plaster casts in the Ponseti treatment, different foot surgeries or the treatment of relapsed or neglected clubfoot. Most trials did not report on harmful effects. When reported, harmful effects during plaster casting included casts slipping, plaster sores and skin irritation. Harmful effects of infection and skin grafting were reported after surgery.

Further well-designed trials are needed to confirm these findings and to decide which is the best treatment for each presentation.

The searches for the review are up to date to April 2013. 


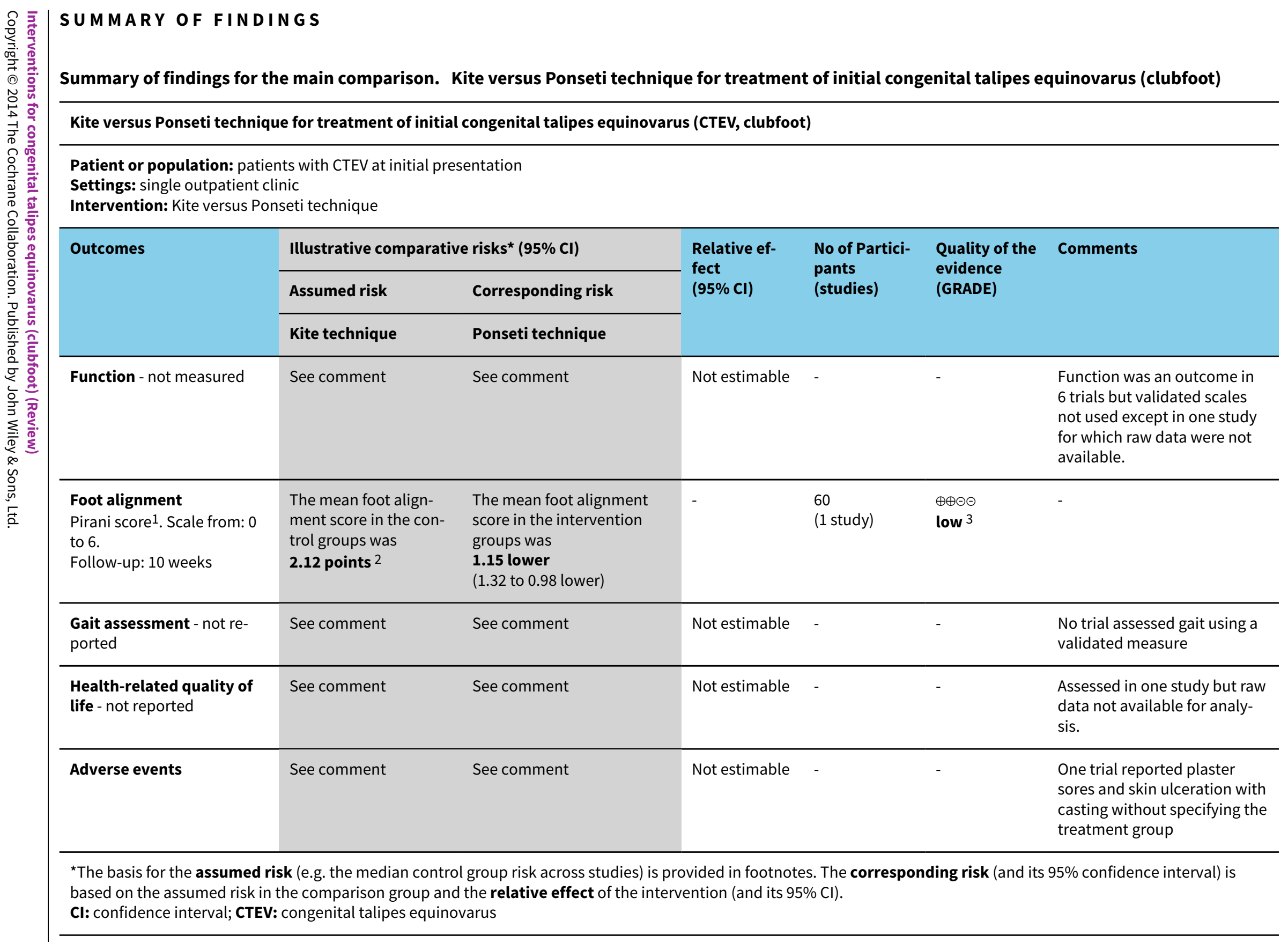


GRADE Working Group grades of evidence

High quality: Further research is very unlikely to change our confidence in the estimate of effect.

Moderate quality: Further research is likely to have an important impact on our confidence in the estimate of effect and may change the estimate.

Low quality: Further research is very likely to have an important impact on our confidence in the estimate of effect and is likely to change the estimate.

Very low quality: We are very uncertain about the estimate.

1 A lower score indicates better alignment.

2 Final mean Ponseti score of pooled results from three strata.

3 There was an overall unclear risk of bias.

Summary of findings 2. Ponseti versus traditional treatment (plaster casting and surgery) for treatment of initial congenital talipes equinovarus (clubfoot)

Ponseti versus traditional treatment (plaster casting and surgery) for treatment of initial congenital talipes equinovarus (CTEV, clubfoot)

Patient or population: patients with CTEV at initial presentation

Settings: single centre

Intervention: Ponseti versus traditional treatment (plaster casting and surgery)

\begin{tabular}{|c|c|c|c|c|c|c|}
\hline \multirow[t]{3}{*}{ Outcomes } & \multicolumn{2}{|c|}{ Illustrative comparative risks ${ }^{\star}(95 \% \mathrm{Cl})$} & \multirow{3}{*}{$\begin{array}{l}\text { Relative ef- } \\
\text { fect } \\
(95 \% \mathrm{Cl})\end{array}$} & \multirow{3}{*}{$\begin{array}{l}\text { No of Partici- } \\
\text { pants } \\
\text { (studies) }\end{array}$} & \multirow{3}{*}{$\begin{array}{l}\text { Quality of the } \\
\text { evidence } \\
\text { (GRADE) }\end{array}$} & \multirow[t]{3}{*}{ Comments } \\
\hline & Assumed risk & Corresponding risk & & & & \\
\hline & $\begin{array}{l}\text { Traditional treatment (plas- } \\
\text { ter casting and surgery) }\end{array}$ & Ponseti technique & & & & \\
\hline $\begin{array}{l}\text { Function } \\
\text { PODCl }\end{array}$ & See comment & See comment & Not estimable & - & See comment & $\begin{array}{l}\text { Data not suitable } \\
\text { for analysis }\end{array}$ \\
\hline $\begin{array}{l}\text { Foot alignment } \\
\text { Pirani score } 1 \text {. Scale from: } 0 \text { to } \\
6 .\end{array}$ & $\begin{array}{l}\text { The mean foot alignment score } \\
\text { in the control groups was } \\
\mathbf{1 . 8} \text { points } 2\end{array}$ & $\begin{array}{l}\text { The mean foot alignment score } \\
\text { in the intervention groups was } \\
\mathbf{1 . 5} \text { lower } \\
\text { ( } 2.28 \text { to } 0.72 \text { lower) }\end{array}$ & - & $\begin{array}{l}28 \\
\text { (1 study) }\end{array}$ & $\begin{array}{l}\oplus \odot \odot \odot \\
\text { very low 3,4,5 }\end{array}$ & - \\
\hline $\begin{array}{l}\text { Gait assessment - not mea- } \\
\text { sured }\end{array}$ & - & - & Not estimable & - & - & - \\
\hline $\begin{array}{l}\text { Health-related quality of } \\
\text { life } \\
\mathrm{PODCI}\end{array}$ & See comment & See comment & Not estimable & - & See comment & $\begin{array}{l}\text { Data not suitable } \\
\text { for analysis }\end{array}$ \\
\hline
\end{tabular}




\begin{tabular}{|c|c|c|c|c|c|c|}
\hline \multicolumn{2}{|l|}{ Adverse events } & See comment & \multicolumn{2}{|l|}{ Not estimable } & ee comment & $\begin{array}{l}\text { There were no } \\
\text { adverse events }\end{array}$ \\
\hline \multicolumn{7}{|c|}{$\begin{array}{l}\text { *The basis for the assumed risk (e.g. the median control group risk across studies) is provided in footnotes. The corresponding risk (and its } 95 \% \text { confidence interval) is } \\
\text { based on the assumed risk in the comparison group and the relative effect of the intervention (and its } 95 \% \mathrm{CI}) \text {. } \\
\text { CI: confidence interval; CTEV: congenital talipes equinovarus; PODCl: Pediatric Outcomes Data Collection Instrument; RR: risk ratio }\end{array}$} \\
\hline \multicolumn{7}{|c|}{$\begin{array}{l}\text { GRADE Working Group grades of evidence } \\
\text { High quality: Further research is very unlikely to change our confidence in the estimate of effect. } \\
\text { Moderate quality: Further research is likely to have an important impact on our confidence in the estimate of effect and may change the estimate. } \\
\text { Low quality: Further research is very likely to have an important impact on our confidence in the estimate of effect and is likely to change the estimate. } \\
\text { Very low quality: We are very uncertain about the estimate. }\end{array}$} \\
\hline \multicolumn{7}{|c|}{$\begin{array}{l}1 \text { A lower score indicates better alignment. } \\
2 \text { Final mean Pirani score in control group. } \\
3 \text { Overall unclear risk of bias. } \\
4 \text { Early stopping rule was instigated. } \\
5 \text { Small number of participants. }\end{array}$} \\
\hline \multicolumn{7}{|c|}{ Standard Ponseti technique versus an accelerated Ponseti technique for congenital talipes equinovarus (CTEV, clubfoot) } \\
\hline \multicolumn{7}{|c|}{$\begin{array}{l}\text { Patient or population: patients with CTEV (type of case (e.g. initial presentation or relapsed) not specified) } \\
\text { Settings: single centre } \\
\text { Intervention: standard Ponseti technique versus an accelerated Ponseti technique }\end{array}$} \\
\hline \multirow[t]{3}{*}{ Outcomes } & \multicolumn{2}{|c|}{ Illustrative comparative risks* $(95 \% \mathrm{Cl})$} & \multirow{3}{*}{$\begin{array}{l}\text { Relative effect } \\
(95 \% \mathrm{CI})\end{array}$} & \multirow{3}{*}{$\begin{array}{l}\text { No of Partici- } \\
\text { pants } \\
\text { (studies) }\end{array}$} & \multirow{3}{*}{$\begin{array}{l}\text { Quality of the } \\
\text { evidence } \\
\text { (GRADE) }\end{array}$} & \multirow[t]{3}{*}{ Comments } \\
\hline & Assumed risk & Corresponding risk & & & & \\
\hline & Standard Ponseti technique & Accelerated Ponseti technique & & & & \\
\hline $\begin{array}{l}\text { Function - not } \\
\text { measured }\end{array}$ & - & - & Not estimable & - & - & - \\
\hline $\begin{array}{l}\text { Foot alignment } \\
\text { Pirani score } 1 \text {. Scale } \\
\text { from: } 0 \text { to } 6 .\end{array}$ & $\begin{array}{l}\text { The median foot alignment } \\
\text { score in the control groups was } \\
\mathbf{0 . 5} \text { points }{ }^{2}\end{array}$ & $\begin{array}{l}\text { The mean foot alignment score in the in- } \\
\text { tervention groups was } \\
\mathbf{0 . 3 1} \text { higher } \\
\text { ( } 0.4 \text { lower to } 1.02 \text { higher) }\end{array}$ & - & $\begin{array}{l}40 \\
\text { (1 study) }\end{array}$ & $\begin{array}{l}\oplus \oplus \oplus \odot \\
\text { moderate } 3\end{array}$ & - \\
\hline
\end{tabular}




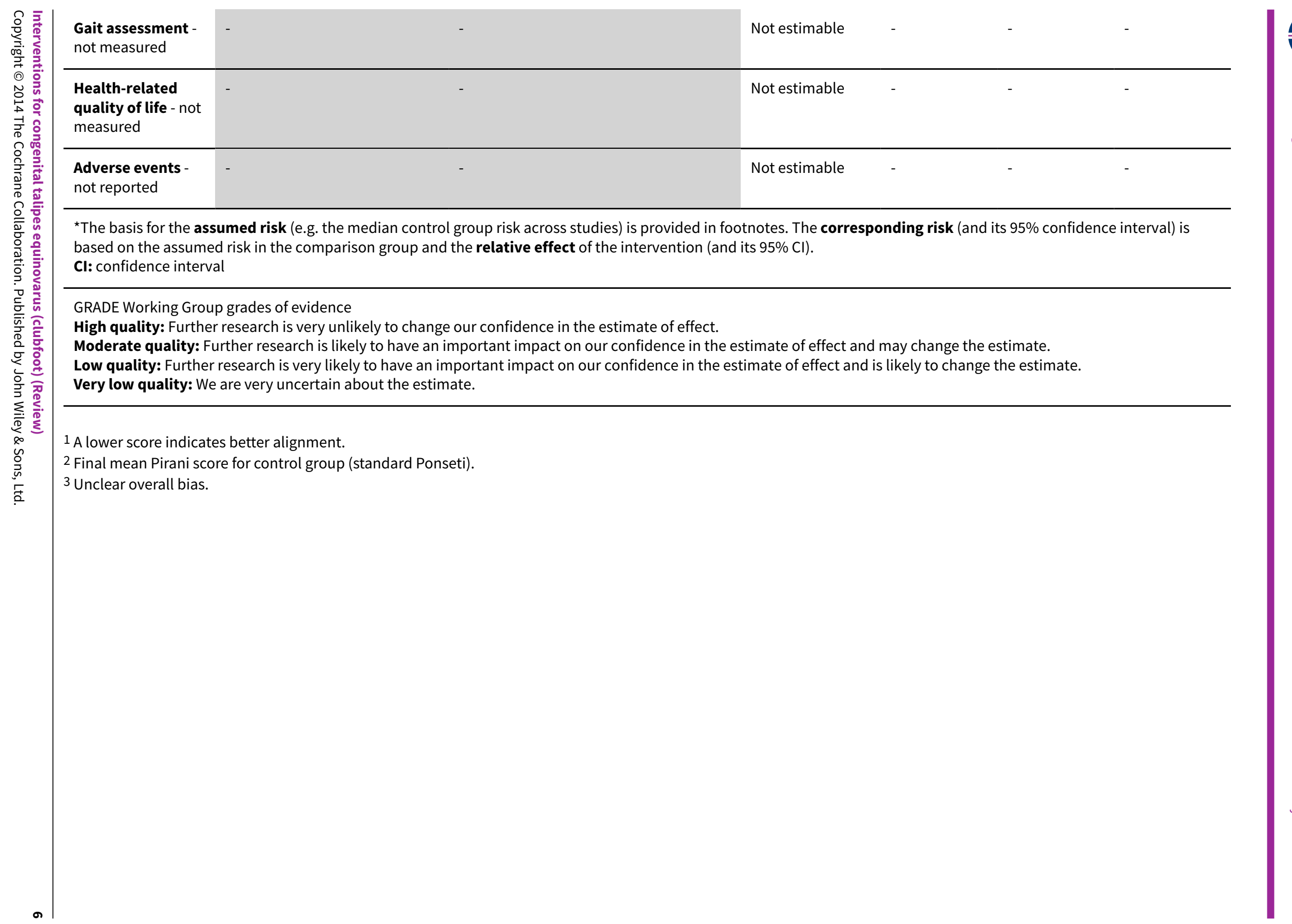




\section{B A C K G R O U N D}

\section{Description of the condition}

Congenital talipes equinovarus (CTEV), also known as clubfoot, is a common congenital paediatric condition, occurring in 1 to 2 per 1000 newborns (Dobbs 2006). It is characterised by an excessively turned in foot (equinovarus) and high medial longitudinal arch (cavus), which if left untreated leads to long-term functional disability, deformity and pain (Ponseti 2005). CTEV is thought to begin as the limb buds form and can be diagnosed on ultrasound from 12 weeks gestation (Keret 2002). There are two types of CTEV: idiopathic (isolated) and syndromic (those associated with other syndromes or conditions). In both the cause is unknown, although hypotheses include associated transient gene activity, as seen in developmental dysplasia of the hips (Ponseti 2005); neuromuscular disease (Handelsman 1982; Lovell 2007); and lack of foetal movement (Hester 2009). Emerging literature suggests a polygenic cause (Dobbs 2009). Syndromic CTEV is often severe and more resistant to treatment (Janicki 2009).

\section{Description of the intervention}

The treatment of CTEV varies but is usually conservative in initial cases, with surgical options reserved for correction of any resistant (remaining) deformity. Conservative treatment includes: stretching, for example the French Functional method (Richards 2008); varied serial casting (plaster casts) and bracing, including Ponseti and Kite techniques (Sud 2007); minor surgical intervention, for example Achilles tenotomy (release of the heel cord), tibialis anterior tendon transfer (moving a muscle in the foot) and Achilles lengthening (lengthening of the calf muscle); the use of external fixator devices (surgical application of a metal brace) (Ponseti 2005); and botulinum toxin injections (Alvarez 2005).

The Ponseti technique is currently the most practised treatment with excellent long-term outcomes (30 years) (Cooper 1995). This technique involves six to eight weeks of long leg plaster casts (toe to groin) with gentle manipulation around the talar head (a part of the ankle joint). Casts are changed once per week. Up to $90 \%$ of cases require an Achilles tenotomy to correct remaining equinus (heel cord tightness) deformity (Haft 2007). This is considered part of routine treatment. Patients are then required to wear a boots and bar brace for 23 hours per day for three months and then during sleep until four years of age (Ponseti 2005). The Ponseti technique has been shown to significantly reduce the need for major foot surgery (Morcuende 2004; Zionts 2010).

The Kite technique was widely practised until the emergence of the Ponseti technique. The Kite technique involves long leg plaster casts (toe to groin) with manipulation occurring around the calcaneo-cuboid joint (a joint in the foot) (Kite 1972). Casting may continue for up to two years (Dobbs 2009) with 50\% to $75 \%$ of cases requiring major surgical intervention (Lovell 1979).

Unfortunately, with all treatments, relapses are common and may occur in up to $37 \%$ of children within two years (Richards 2008) and in up to $47 \%$ before four years of age (Laaveg 1980). Causes of relapse include non-compliance with bracing regimes (such as the Ponseti method) (Morcuende 2004), relative overactivity of the tibialis anterior tendon (Ponseti 2005) and progressive neuromuscular disease (Lovell 2007; Masrouha 2012). When left untreated, the foot gradually returns to its original position. In mild cases the child may overload the lateral border of their foot during walking and in extreme cases walk on the outside border of the foot (cuboid and fifth metatarsal) with resulting callosities and pain.

In children with relapsed CTEV, intervention is required to prevent further progressive deformity. Historically, relapses were treated with major surgical intervention including muscle, ligament and joint releases (for example posteromedial soft tissue release) or bony operations (for example wedge osteotomies) (Dobbs 2000). Long-term observational studies have found poorer outcomes in patients treated with major foot surgery (Dobbs 2006; Graf 2010; Ippolito 2003). Clinicians are therefore beginning to employ the same conservative techniques used in initial CTEV to treat relapses (Nogueira 2009).

\section{How the intervention might work}

Frequent stretching and active assisted movement (for example the French functional method) has been shown to be effective in achieving good joint alignment in patients less than two years old with CTEV (Richards 2007).

Serial plaster casting (for example the Ponseti and Kite techniques), involving sustained stretching for an extended period, is thought to improve the extensibility of surrounding tissue and joint capsules. Magnetic resonance imaging studies of babies with CTEV show that musculature, ligament and bony changes are possible with weekly Ponseti casting (Pirani 2001). Studies have demonstrated increases in both the length and numbers of sarcomeres when a muscle is immobilised in a lengthened position for an extended period of time (Cusick 1990).

Minor surgical procedures, those which are joint sparing (do not involve the ankle or foot joints), are thought to result in good longterm outcomes, with pain-free feet (Dietz 2006). Examples include Achilles tenotomies (surgically releasing the Achilles tendon), which have been shown in very young children to result in direct elongation of the tendon (De Gheldere 2008; Radler 2007) and tibialis anterior tendon transfer, which aims to restore the balance of musculature around the foot by making the tibialis anterior muscle pull the foot directly up rather than up and twisting in (with the big toe up) (Kuo 2001; Laaveg 1980). In severe cases, relapsed CTEV may require a combination of these procedures or major bone or joint surgery to correct the position of the foot and ankle.

Botulinum toxin, a potent neuromuscular agent, causes partial temporary muscular paralysis allowing for lengthening through sustained stretching (for example serial casting). When used in the triceps surae (calf muscle), it may prevent the need for Achilles tenotomy or other major surgery (Alvarez 2005).

\section{Why it is important to do this review}

The treatment of CTEV remained varied and inconsistent until the Ponseti technique became widely practised. This technique has shown favourable long-term outcomes (Cooper 1995), but relapses are common. A systematic review of all interventions for initial and relapsed CTEV will assist the clinician in providing the most effective treatment and allow for ongoing evaluation of these interventions in the future. This review was first published in 2012 and updated in 2013. 


\section{O B JECTIVES}

To evaluate the effectiveness of interventions for CTEV.

\section{METHODS}

\section{Criteria for considering studies for this review}

\section{Types of studies}

All randomised controlled trials (RCTs) or quasi-RCTs of interventions for the treatment of CTEV. Quasi-RCTs are those where systematic methods of allocation are used, for example date of birth, hospital number or date.

\section{Types of participants}

People of all ages with CTEV of either one or both feet.

\section{Types of interventions}

We included any intervention aimed at reducing or eliminating the deformity associated with CTEV (for example cavus, adductus, varus and equinus), including but not limited to the following:

- stretching, for example passive and active stretching using taping or plaster casts (serial casting);

- surgery, for example muscle lengthening, tendon transfers, osteotomies (operations on bone) and external fixators (surgically applied brackets which can stretch joints); and

- other, for example botulinum toxin.

\section{Types of outcome measures}

The outcomes listed here are not eligibility criteria for this review, but are outcomes of interest within whichever studies are included.

\section{Primary outcomes}

- Function: self reported or parent- or proxy-reported day-to-day function at a minimum of one year post-treatment, as measured by any validated assessment tool, for example Clubfoot Disease Specific Index (DSI) (Dietz 2009); physical component of the Child Health Questionnaire (CHQ) (Landgraf 1999) and physical subscale of the Short Form 36 Health Survey (SF-36) (Ware 1992).

Studies with different follow-up periods were to be combined with appropriate adjustments if the assumption of steady rates of change were justified. This was not possible with the data available.

\section{Secondary outcomes}

- Foot alignment (measured by any validated assessment tool, for example, radiographic, Foot Posture Index (Redmond 2006), Dimeglio scale (Diméglio 1995), Pirani score (Pirani 2008)).

- Gait assessment (for example, pedobarography, 3D kinematics).

- Parent- or patient-reported health-related quality of life (measured by any validated assessment tool, for example, $\mathrm{CHQ}$ ).

- Adverse events (classified as 'any adverse event', 'adverse event leading to withdrawal of treatment', and 'life-threatening (severe) adverse event' (requiring admission to hospital or adverse outcome leading to permanent disability or death)).

Measures were to be assessed at a minimum of one year; however, some outcomes (for example foot alignment) measured at the end of treatment determined whether further alternative treatment (such as surgery) was required. We have therefore included significant findings (clinically or statistically) at the end of treatment where indicated.

We planned to combine studies with different follow-up periods with appropriate adjustments if the assumption of steady rates of change were justified; however, this was not possible with the data available. We presented the following outcomes in 'Summary of findings' tables as far as data allowed:

- function (self reported or parent- or proxy-reported);

- foot alignment;

- gait assessment;

- health related quality of life; and

- adverse events.

\section{Search methods for identification of studies}

\section{Electronic searches}

On 29 April 2013, we searched CENTRAL (2013, Issue 3, in The Cochrane Library), MEDLINE (January 1966 to April 2013), EMBASE (January 1980 to April 2013), AMED (January 1985 to April 2013), CINAHL Plus (January 1937 to April 2013), PEDro (January 1929 to April 2013). We searched the WHO International Clinical Trials Registry Platform (ICTRP) (2006 to July 2013) (www.who.int/ictrp/ en/) and ClinicalTrials.gov (www.clinicaltrials.gov) for ongoing trials. There were no language or publication restrictions. We searched NHS Economic Evaluation Database (NHSEED), Database of Abstracts of Reviews of Effectiveness (DARE) and Health Technology Assessment Database (HTA) (2013, Issue 1 in The Cochrane Library), for information to include in the Discussion,

The detailed search strategies are shown in the Appendices: CENTRAL and NHSEED, Appendix 1; MEDLINE, Appendix 2; EMBASE, Appendix 3; AMED, Appendix 4; CINAHL Plus, Appendix 5; PEDro Appendix 6; WHO ICTRP, Appendix 7 and ClinicalTrials.gov, Appendix 8.

\section{Searching other resources}

We reviewed the bibliographies of the trials identified and, if appropriate, contacted the authors as well as known experts in the field to identify additional studies. We handsearched the reference sections of retrieved articles, relevant thesis publications and the reports or conference proceedings of relevant symposia, for example the International Clubfoot Symposium. We contacted registered expert clinicians in the field to identify additional published or unpublished data. We specified no limitations on language or year published.

\section{Data collection and analysis}

\section{Selection of studies}

Two review authors (KG and VP) independently assessed the titles and abstracts of trials identified by the search. The same two authors reviewed full text copies of potentially relevant trials to determine eligibility based on inclusion criteria.

We did not mask study authorship and results during the study selection process as the effect of assessor masking has not been established by empirical evidence (Higgins 2008c). The review authors resolved disagreements by discussion and, if necessary, arbitration by a third review author (JB). Arbitration by the third 
reviewer resolved all disputes so we did not contact study authors for additional information.

\section{Data extraction and management}

Two review authors (KG and VP) independently extracted data using separate, standardised, prepared forms. We contacted trial authors to provide any missing information. One review author (KG) entered data into the Cochrane statistical software, Review Manager (RevMan 2008), and a second (VP) checked the data entry. The review authors resolved disagreements by discussion and, if necessary, arbitration by a third author (JB).

\section{Assessment of risk of bias in included studies}

Two review authors (KG and VP) independently rated the risk of bias in the reviewed studies using a standardised grading system described in the Cochrane Handbook for Systematic Reviews of Interventions (Higgins 2008, updated Higgins 2011). There were no disagreements between the authors for assessment of risk of bias. Any disagreements would have been resolved by discussion and, if necessary, arbitration by a third author (JB). The grading system considered the following domains:

- sequence generation;

- allocation concealment;

- blinding of participants, personnel and outcome assessors;

- other potential threats to validity (such as financial conflicts of interest, single author or single centre trials);

- incomplete outcome data; and

- selective outcome reporting.

We created a 'Risk of bias' table for each included study showing our judgement for each domain. We used judgements of 'High risk of bias', 'Low risk of bias' or 'Unclear risk of bias', where 'Unclear risk of bias' indicates an unknown risk of bias or that an entry is not relevant to the study. We included a comment to support each of our assessments. We generated a 'Risk of bias summary' using RevMan to present all of the judgements in a cross-tabulation of study by risk of bias domain.

\section{Measures of treatment effect}

If there was more than one trial with a specific intervention we planned to perform a meta-analysis using RevMan. Where the same outcome measures were used, we planned to calculate mean differences (MD) and 95\% confidence intervals (Cls) for continuous variables. Where outcome measures differed but measured the same construct, we planned to calculate standardised mean differences (SMD) and 95\% Cls. For dichotomous outcomes, we planned to determine risk ratios (RRs) and $95 \%$ Cls using a fixedeffect model, where heterogeneity permitted (see Assessment of heterogeneity).

\section{Unit of analysis issues}

Although we planned to include cross-over trials, there were none. If we had identified cross-over trials we planned to use the generic inverse variance (GIV) facility in RevMan to combine the estimated difference in effects from each study with its standard error (SE).

A number of trials included data from bilateral (including both right and left feet) and unilateral cases. In bilateral cases, right and left feet from the same subject are likely to be correlated (not independent). An analysis that ignores this correlation will provide $\mathrm{Cls}$ and $\mathrm{P}$ values that are invalid, and may detect spurious significance. However, there are statistical techniques available to overcome this. Where raw data was available (Harnett 2011), we used a linear mixed model with random subject effects. As well as providing a valid analysis of this study, the linear mixed model gave an estimate of the correlation between measurements taken from left and right feet in participants who received the same intervention. Making the assumption that this correlation was consistent in other trials with the same outcome variable, we were able to adjust results and re-analyse published data. We have provided details of each analysis in the description of each study.

\section{Dealing with missing data}

If the study authors had not performed an intention-to-treat analysis, we would have done so before entry of data into RevMan, provided sufficient data were available.

\section{Assessment of heterogeneity}

We assessed clinical heterogeneity across trials; however, none were sufficiently clinically homogenous in terms of participants, intervention, and outcomes to include them in a meta-analysis.

\section{Assessment of reporting biases}

We took the following measures to reduce reporting biases.

- We performed comprehensive searches to identify randomised, quasi randomised and cross-over trials.

- We sought to include unpublished relevant studies, including those registered at inception.

- If it had been possible, we planned to detect reporting biases using funnel plots to assess for small study effects (Higgins 2008b).

\section{Data synthesis}

We used RevMan for data analysis. One author (KG) entered statistical data and a second review author (VP) checked the data entry. We resolved all disagreements by discussion with a third review author $(\mathrm{JB})$.

\section{Subgroup analysis and investigation of heterogeneity}

The following predefined subgroup analyses would have been performed if sufficient data had been available.

1. Age: birth to two years, two to four years, four to 10 years, 10 to 20 years, and over 20 years of age (relapses are most common in the birth to two year range and decrease with age). The literature has previously reported subgroup analysis (Laaveg 1980; Richards 2008).

2. Unilateral versus bilateral CTEV.

3. Idiopathic versus syndromic CTEV (associated with other conditions).

4. Initial versus relapsed CTEV.

We would have followed the same methodological principles for meta-analysis of subgroups as for the primary analysis.

\section{Sensitivity analysis}

If clinical heterogeneity had been present, we planned to carry out a sensitivity analysis by omitting from the meta-analysis trials 
at high risk of bias, or which were unpublished, or funded by industry. We would have made omissions in order, for example we would have removed studies with unclear or inadequate allocation concealment, re-run the analysis, then removed studies with unclear blinding and re-run the analysis, and so on.

If data had been available, we planned to include cost-benefit analysis of interventions for the treatment of CTEV in the Discussion, making use of the non-randomised data where necessary.

\section{Risk of bias in the review process}

The review has a published protocol (Gray 2010). We have documented any deviations from the protocol in Differences between protocol and review.

\section{RE S U L T S}

\section{Description of studies}

\section{Results of the search}

Electronic searches retrieved 460 citations (CENTRAL 48, MEDLINE 254, EMBASE 107, CINAHL Plus 12, AMED 21, and PeDRO 5). Fortythree studies were identified as potentially relevant. Searching reference lists of included trials did not identify any additional potentially relevant trials. Our search of WHO ICTRP revealed 21 studies and ClinicalTrials.gov revealed 28 studies. None were included in the review as Ongoing studies.

There were 2 papers in NHSEED and none in DARE or HTA databases.

\section{Included studies}

Fourteen trials met the criteria for inclusion in the review (Cummings 2009; El-Deeb 2007; Harnett 2011; Kaewpornsawan 2007; Lahoti 2008; Manzone 1999; Pittner 2008; Rijal 2010; Sanghvi 2009; Selmani 2012; Siddiqui 2007; Sud 2008; Zeifang 2005; Zwick 2009). Electronic searching identified all these trials. Details of individual trials are presented in the tables Characteristics of included studies and 'Characteristics of included trials' (Table 1).
Seven trials were parallel-designed RCTs (Cummings 2009; Harnett 2011; Kaewpornsawan 2007; Rijal 2010; Selmani 2012; Zeifang 2005; Zwick 2009), three were quasi-RCTs (El-Deeb 2007; Pittner 2008; Sud 2008) and the remaining four were randomised but the method was not described (Lahoti 2008; Manzone 1999; Sanghvi 2009; Siddiqui 2007). The duration of follow-up averaged 25 months and ranged from end of treatment (Harnett 2011; Pittner 2008; Rijal 2010; Siddiqui 2007) to 48 months (Lahoti 2008; Zeifang 2005). All trials were published in the English language in peer reviewed journals between 1999 and 2013.

Eight trials assessed treatment in participants without any prior intervention (initial presentation) (Cummings 2009; Manzone 1999; Pittner 2008; Rijal 2010; Sanghvi 2009; Selmani 2012; Sud 2008; Zwick 2009), four assessed treatment in resistant cases (those who had undergone prior intervention without full correction of the deformity) (El-Deeb 2007; Kaewpornsawan 2007; Lahoti 2008; Zeifang 2005) and two did not state if there had been a prior intervention (Harnett 2011; Siddiqui 2007).

\section{Excluded studies}

We excluded 29 potentially relevant studies after reading full-text versions. Twenty-eight were not RCTs (Andriesse 2008; Atar 1993; Aurell 2005; Chang 1991; DePuy 1989; DeRosa 1986; Dimeglio 1996; Doğan 2002; Farsetti 2009; Faulks 2009; Halanski 2010; Ippolito 2003; Janicki 2011; Kesemenli 2003; Kuo 2001; Li 2007; Miura 2005; Napiontek 2000; Narang 2011; Nilgün 2011; O'Brien 2004; Ponseti 2006; Richards 2008; Simons 1985; Steinman 2009; Tschopp 2002; Uglow 2000; Xu 2011) and one study did not state whether randomisation was undertaken (Thompson 1982).

\section{Risk of bias in included studies}

All studies displayed potential risk of bias in at least four areas. One trial had an overall high risk of bias (Sud 2008). The remaining 13 trials (Cummings 2009; El-Deeb 2007; Harnett 2011; Kaewpornsawan 2007; Lahoti 2008; Manzone 1999; Pittner 2008; Rijal 2010; Sanghvi 2009; Selmani 2012; Siddiqui 2007; Zeifang 2005; Zwick 2009) had unclear risks of bias. Review authors' judgements about each risk of bias item for each included study are summarised in Figure 1. 
Figure 1. Risk of bias summary: review authors' judgements about each risk of bias item for each included study. Green = low risk of bias; yellow = unclear risk of bias; red = high risk of bias.

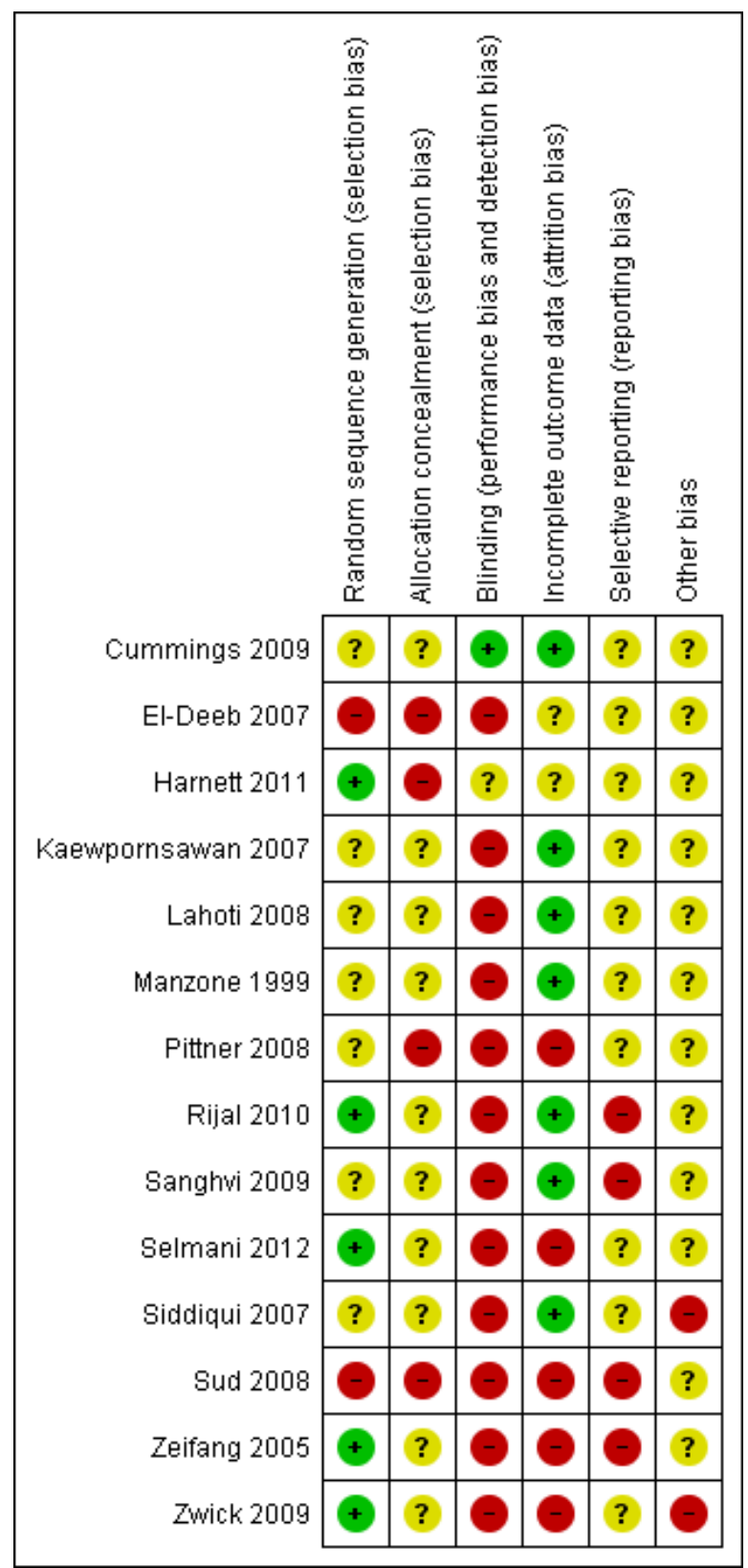

\section{Allocation}

Participants in eight trials were randomly allocated to treatment groups using computer number generation (Harnett 2011; Rijal 2010; Selmani 2012; Zeifang 2005), medical record numbers (Pittner 2008), random number table (Zwick 2009), random selection of unmarked vials (Cummings 2009) and unmarked envelopes (Kaewpornsawan 2007). Quasi-randomisation occurred in two trials that used sequencing based on arrival (El-Deeb 2007; Sud 2008). Four trials did not state the method of randomisation. (Manzone 1999, Lahoti 2008; Sanghvi 2009; Siddiqui 2007). Concealment of allocation was not adequate in any trial. Three trials had inadequate concealment (El-Deeb 2007; Pittner 2008; Sud 2008) and the remaining eleven trials (Cummings 2009; Harnett 2011; Kaewpornsawan 2007; Lahoti 2008; Manzone 1999; Rijal 2010;
Sanghvi 2009; Selmani 2012; Siddiqui 2007; Zeifang 2005; Zwick 2009) were unclear, owing to insufficient information.

\section{Blinding}

It was not possible to blind the intervention provider in any included trial. Participants were blinded to the intervention in one trial (Cummings 2009), in which participants received either botulinum toxin or a placebo. The remaining trials provided insufficient information on blinding of participants. Outcome assessors were blinded to the intervention in six trials (Cummings 2009; Lahoti 2008; Rijal 2010; Selmani 2012; Sud 2008; Zeifang 2005) and were not blinded in three (Pittner 2008; Sanghvi 2009; Zwick 2009). The remaining five trials (El-Deeb 2007; Harnett 
2011; Kaewpornsawan 2007; Manzone 1999; Selmani 2012; Siddiqui 2007) provided insufficient information to permit judgement.

\section{Incomplete outcome data}

Seven trials had no missing data (Cummings 2009; Kaewpornsawan 2007; Lahoti 2008; Manzone 1999; Rijal 2010; Sanghvi 2009; Siddiqui 2007). Four had missing data which were not addressed (Pittner 2008; Selmani 2012; Sud 2008; Zeifang 2005). Missing data in two trials (Harnett 2011; Zwick 2009) were addressed by an intention-totreat analysis but several participants broke protocol by changing treatment arms. El-Deeb 2007 provided insufficient information to determine the risk of bias from incomplete outcome measures.

\section{Selective reporting}

Two studies had incomplete reporting: in one of them outcomes could not be reported because of missing data (Sanghvi 2009) and the other (Sud 2008) did not report on outcomes defined in the materials and methods. Five trials had identifiable selective reporting (Rijal 2010; Sanghvi 2009; Selmani 2012; Sud 2008; Zeifang 2005). The remaining nine trials (Cummings 2009; El-Deeb 2007; Harnett 2011; Kaewpornsawan 2007; Lahoti 2008; Pittner 2008; Rijal 2010; Siddiqui 2007; Zwick 2009) were assessed as unclear, as there was insufficient information to make a judgement.

\section{Other potential sources of bias}

Two trials had other identifiable sources of bias. Zwick 2009 had a formal stopping rule as one treatment arm was leading to much greater rates of major surgical intervention. Siddiqui 2007 reported on a procedure the authors had developed. All remaining trials were considered to have an 'Unclear risk of bias' for this domain, owing to insufficient information on baseline characteristics (Cummings 2009; El-Deeb 2007; Kaewpornsawan 2007; Lahoti 2008; Manzone 1999; Sanghvi 2009) or insufficient information to permit judgement (Harnett 2011; Pittner 2008; Rijal 2010; Selmani 2012; Sud 2008; Zeifang 2005).

\section{Effects of interventions}

See: Summary of findings for the main comparison Kite versus Ponseti technique for treatment of initial congenital talipes equinovarus (clubfoot); Summary of findings 2 Ponseti versus traditional treatment (plaster casting and surgery) for treatment of initial congenital talipes equinovarus (clubfoot); Summary of findings 3 Standard Ponseti technique versus an accelerated Ponseti technique for congenital talipes equinovarus (clubfoot)

Eleven comparisons were reported. Five trials compared the Ponseti technique with other treatments: the Kite technique (Rijal 2010; Sanghvi 2009; Selmani 2012; Sud 2008) and traditional casting with surgery (Zwick 2009). Three trials examined modification of the Ponseti technique, one by different casting materials (Pittner 2008), one by the addition of botulinum toxin A (Cummings 2009) and one by use of an accelerated Ponseti treatment schedule (Harnett 2011). Five trials compared different major surgical interventions (El-Deeb 2007; Kaewpornsawan 2007; Lahoti 2008; Manzone 1999; Siddiqui 2007) and one compared two postoperative regimes (Zeifang 2005). Details of interventions are provided in the tables Characteristics of included studies and Table 1 , 'Characteristics of included trials'. Comparisons are ordered in groups: treatment for initial presentations (comparisons 1 to 6), treatment for resistant cases (comparisons 7 to 10) and other presentations (comparison 11).

\section{Participants}

A total of 607 participants with CTEV were included. In trials assessing initial treatment there were 326 participants (487 feet) and in trials assessing resistant deformity there were 181 participants (256 feet). Two reports were unclear: Harnett 2011 treated 40 participants ( 61 feet), but did not state the timing of the intervention and Siddiqui 2007 included 60 participants but did not state the number of included feet. The number of participants ranged from 13 ( $26 \mathrm{feet}$ ) to 100 (150 feet). Of the ten trials for which adequate details were reported, 298 (64\%) participants were male and 168 (36\%) were female. Lahoti 2008 did not report on gender. Pittner 2008, Zeifang 2005 and Sud 2008 reported drop-outs prior to data analysis.

Of the eight trials assessing initial treatment, two reported an average age of participants: 16.3 months (Rijal 2010) and 7.7 months (Manzone 1999). Two specified age ranges: less than two weeks (Zwick 2009), and 0 to 30 days (Cummings 2009). Sanghvi 2009 included a range of age groups from birth to greater than 36 weeks. Following removal of drop-out data, participants in Pittner 2008 had an average age of 10 days, Selmani 2012 an average of 33 days, and in Sud 2008, an average age of 29 days.

In the four trials that assessed treatment for resistant CTEV, participants had an average age of 8.3 months.

In the two unclear trials, Harnett 2011 included participants less than 90 days old and participants in Siddiqui 2007 had an average age of 9.6 months.

Inclusion of idiopathic cases was specified in three of the seven trials assessing initial treatment (Manzone 1999; Rijal 2010; Selmani 2012). A further three trials stated exclusion of CTEV cases associated with syndromes or with other deformities (Sanghvi 2009; Sud 2008; Zwick 2009). Cummings 2009 and Pittner 2008 did not report inclusion or exclusion criteria. Of the four trials assessing treatment of resistant CTEV, two specified idiopathic CTEV as an inclusion criterion (El-Deeb 2007; Zeifang 2005) and one specifically excluded syndromic CTEV or similar cases (Kaewpornsawan 2007). Lahoti 2008 included two feet (1 participant) with syndromic CTEV. Of the unclear trials, Harnett 2011 included idiopathic cases and Siddiqui 2007 did not report on inclusion or exclusion criteria.

\section{Statistical considerations}

Several studies were comparable, with similar treatment and participant cohorts; however they employed different outcome measures, which precluded pooling for meta-analysis. Nine authors responded to requests for additional information. One author was able to provide raw data in order to perform re-analysis (Harnett 2011).

A linear mixed model was used in the analysis of raw data for Harnett 2011. This assumed that outcomes were normally distributed; however, Pirani scores are not normally distributed, so we used a computed bootstrap $\mathrm{Cl}$ as a check on the robustness of the results from this study. Exact details are given in the description of the results from this study. 


\section{Outcomes}

\section{Primary outcome}

Function was an outcome in six trials (El-Deeb 2007; Kaewpornsawan 2007; Manzone 1999; Sanghvi 2009; Sud 2008; Zwick 2009). Only one used a validated functional scale, the Pediatric Outcomes Data Collection Instrument (PODCI) (Zwick 2009) but raw data were not available for analysis.

\section{Secondary outcomes}

Radiography was an outcome in four trials (El-Deeb 2007; Manzone 1999; Sanghvi 2009; Zwick 2009) but raw data were not available for analysis.

Foot alignment was assessed in all trials. Foot alignment is a key outcome used at the end of initial treatment to determine the next course of treatment (for example bracing or major foot surgery).

Seven trials used validated scales specific to CTEV: the Dimeglio scale (Pittner 2008; Zeifang 2005) and the Pirani score (Harnett 2011; Lahoti 2008; Rijal 2010; Selmani 2012; Zwick 2009). Both scores assess several components of foot alignment. The sums of these scores form a final severity score; in both scales a higher score correlates with greater severity. Further detail on the Pirani score can be found in Table 2 (Pirani 2008). No raw data from the Dimeglio scale were available for analysis. Harnett 2011 provided raw Pirani score data, and statistical analysis of this raw data allowed for analysis of all published Pirani data.

No trial investigated gait using a validated method.

Parent- or patient-reported health-related quality of life was assessed in one trial (Zwick 2009), using the PODCl.

Adverse events were documented in six trials (Kaewpornsawan 2007; Manzone 1999; Pittner 2008; Sanghvi 2009; Siddiqui 2007; Zwick 2009). In two trials involving plaster casting treatment, Sanghvi 2009 reported plaster sores and skin ulceration (five participants, 8\%) and Pittner 2008 reported minor skin irritation and plaster casts slipping (11 participants, 35\%). The groups in which these events occurred was not stated. In trials that assessed surgical interventions, the incidence of adverse events was reported in four (Kaewpornsawan 2007; Manzone 1999; Siddiqui 2007; Zwick 2009). Manzone 1999 reported superficial infections (two feet) requiring antibiotics and skin breakdown. One foot required skin grafting. Kaewpornsawan 2007 reported skin infections in both groups: posteromedial soft tissue release (four feet, $8.5 \%$ ) and complete circumferential subtalar release (two feet, $5.1 \%)$. Siddiqui 2007 reported wound infections in both groups: window procedure (one foot, $3 \%$ ) and the Turco procedure (six feet, $20 \%$ ). The Turco procedure also produced skin breakdown and wound dehiscence (opening) (two feet, 7\%). Zwick 2009 reported no complications in either treatment group. Adverse events were not addressed in the remaining trials.

Relapse was documented in 13 trials. In initial cases, in up to three years of follow-up, three trials reported relapse with Ponseti and Kite techniques (Sanghvi 2009; Selmani 2012; Sud 2008). Selmani 2012 did not report what treatment was required to correct the 11 feet in the Kite group. In the two feet of the Ponseti group which required surgery, the type of surgery was not stated. Sanghvi 2009 and Sud 2008 found the risk difference for major surgery following relapse was $25 \%$ and $50 \%$ higher in the Kite group respectively. Meta-analysis was not performed due to small numbers. In resistant CTEV all cases of relapse required major foot surgery to correct.

\section{Initial Cases}

Eight trials investigated treatment for initial presentation of CTEV.

\section{Comparison 1: Ponseti versus Kite technique}

Four studies compared Ponseti versus Kite techniques (Rijal 2010; Sanghvi 2009; Selmani 2012; Sud 2008). All trials included cases of idiopathic CTEV only. We could analyse foot alignment data (Pirani scores) from one trial (Rijal 2010). The Pirani score is scored from zero to six and a higher score indicates worse alignment. Results were analysed at the end of 10 weeks of serial casting and published in three strata. All strata found the Ponseti technique to be superior to the Kite technique (Analysis 1.1, Figure 2). 
Figure 2. Forest plot of comparison: 1 Kite versus Ponseti technique for treatment of initial CTEV. Pirani score after 10 weeks of serial casting.

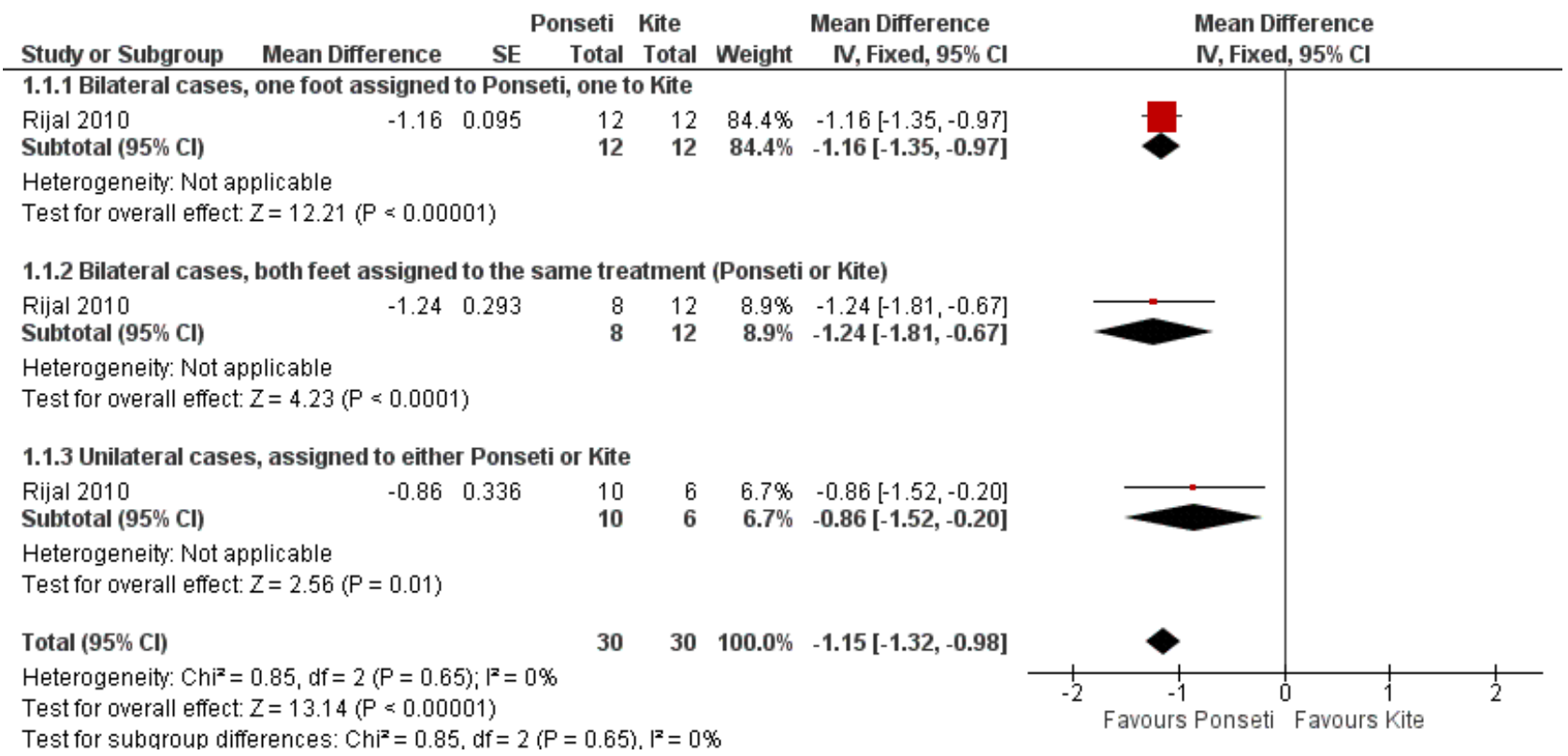

Strata 1 (12 participants, 24 feet) consisted of the randomised participants with bilateral CTEV, where one foot was treated with the Ponseti technique and the other with the Kite technique. At the end of serial casting, the mean (SDs) of the total Pirani scores were $1.20(0.57)$ in the Ponseti group versus $2.36(0.67)$ in the Kite group. To calculate a valid SE for the difference between these means the matching needs to be taken into account, since there may be within (intrinsic) patient differences (for example ligament laxity). This requires knowledge of the correlation between measurements on left and right feet. Since this is unknown in this study, we used the estimate from the Harnett 2011 study.

The estimated MD is 1.16 (2.36 minus 1.20). Assuming that the correlation between means is 0.8704 (calculated from raw Harnett 2011 data), the SD of within subject differences is $0.330\left(0.330^{2}=\right.$ $0.572+0.672-2 \times 0.874 \times 0.67 \times 0.57)$ and hence the SE of the MD is $0.095(0.330 / \sqrt{ } 12)$, giving a $95 \% \mathrm{Cl}$ for the difference of 0.97 to 1.35 .

Strata 2 (10 participants, 20 feet) consisted of the randomised participants with bilateral CTEV, where both feet received the same treatment (four participants the Ponseti technique and six the Kite technique). Denoting the mean of the left and right scores as the combined score, analysis can compare the group- specific means of these combined scores. At the end of serial casting, the mean (SDs) of the total Pirani scores in the Ponseti group for left feet were $0.62(0.48)$ versus $1.00(0.41)$ in right feet. Assuming that the correlation between right and left feet from the same subject is 0.8704 , the mean of the combined scores ((left + right) / 2$)$ is 0.81 and the SD is $0.430\left(0.430^{2}=\left(0.48^{2}+0.41^{2}+2 \times 0.8704 \times 0.48 \times\right.\right.$ $0.41)$ / 4). At the end of serial casting, the total Pirani scores in the Kite group were 2.1 (0.68) for left feet and $2.00(0.32)$ for right feet. Therefore, the average combined score was 2.05 and the SD was $\left.0.486\left(0.486^{2}=0.68^{2}+0.32^{2}+2 \times 0.8704 \times 0.68 \times 0.32\right) / 4\right)$. Accordingly, the estimated difference of means between groups was $1.24(2.05$ minus 0.81$)$ and the SE was $0.293\left(0.293^{2}=\left(0.430^{2} /\right.\right.$ $4)+\left(0.486^{2} / 6\right)$, giving a $95 \% \mathrm{Cl}$ for the difference of 0.67 to 1.81 .
Strata 3 (16 participants, 16 feet) consisted of the randomised participants with unilateral CTEV. Ten participants were treated with the Ponseti technique and six with the Kite technique. At follow-up, the mean (SDs) of the total Pirani scores were 1.05 $(0.49)$ in the Ponseti group versus $1.91(0.73)$ in the Kite group. The estimated difference of the means between groups was $0.86(1.91$ minus 1.05) and the SE was $0.336\left(0.336^{2}=\left(0.49^{2} / 10\right)+\left(0.73^{2} / 6\right)\right)$, giving a $\mathrm{Cl}$ for the difference of 0.20 to 1.52 .

Pooling the results from the three strata gave an MD of $1.15(95 \% \mathrm{Cl}$ 0.98 to 1.32 ) in favour of the Ponseti technique (Analysis 1.1, Figure 2).

Significant outcomes should be viewed with caution as all groups contained small numbers. Relapses were seen in both groups. Sanghvi 2009 and Sud 2008 found the risk difference for major surgery following relapse was $25 \%$ and $50 \%$ higher in the Kite group respectively. Meta-analysis was not performed due to small numbers. Details of relapse are provided in Table 3 'Details of relapse. Ponseti versus Kite'.

\section{Comparison 2: Ponseti technique versus traditional treatment (serial casting followed by posteromedial soft tissue release)}

One trial compared Ponseti to a traditional treatment in idiopathic CTEV (Zwick 2009). We were able to analyse foot alignment data (Pirani scores).

Participants were randomised to either Ponseti (nine participants, 12 feet) or traditional technique (10 participants, 16 feet). Published mean (SD) total Pirani scores were $0.3(0.3)$ in the Ponseti group (at the completion of serial casting and tenotomy) and $1.8(1.2)$ in the traditional group (at the completion of a different type of serial casting). Assuming that the correlation between right and left foot scores from the same subject is $r$, the standard error of the mean of $N$ observations from $n$ subjects with SD $\sigma$, is given by $\sigma(N+2 r$ $(N-n))^{0.5 / N}$. Therefore the estimated SE of the mean is 0.104 in the Ponseti group and 0.386 in the traditional group. The estimated SE 
Figure 3. Forest plot of comparison: 2 Ponseti versus traditional treatment (plaster casting and surgery) for treatment of initial CTEV. Pirani score at end of initial Ponseti (serial plaster casting and tenotomy) and traditional treatment (serial plaster casting only).

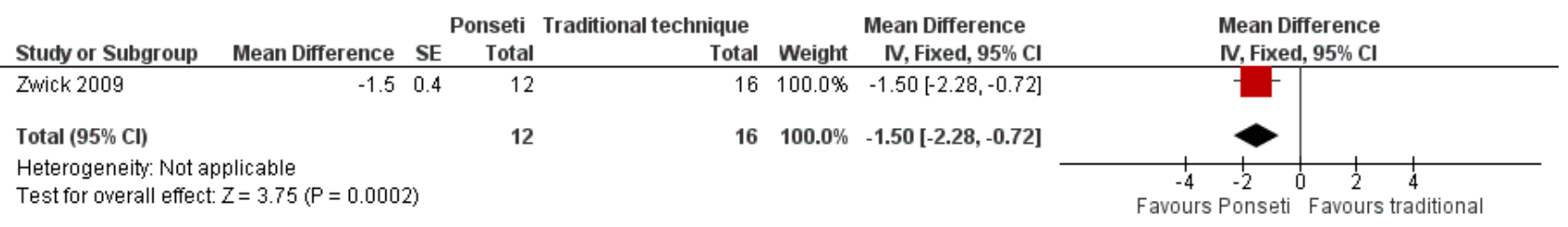

Relapse was seen in two of nine participants in the Ponseti group within two months of completion of serial casting. Both changed to the traditional group and underwent major surgery.

\section{Comparison 3: Ponseti technique, plaster of Paris versus semi- rigid casting}

One trial compared plaster of Paris to semi-rigid casting (Pittner 2008). It was not stated if cases were idiopathic. We were unable to estimate a treatment effect because data from a validated assessment method to collect primary or secondary outcomes were not available.

\section{Comparison 4: Ponseti technique, addition of botulinum toxin versus placebo}

One study assessed the addition of botulinum toxin to the Ponseti technique (Cummings 2009). It was not stated if cases were idiopathic. We were unable to estimate a treatment effect as data from validated outcome measures were not available. Relapses were reported in both groups but data was not available to analyse.

\section{Comparison 5: posteromedial soft tissue release versus circumferential subtalar release}

One study assessed posteromedial soft tissue release versus circumferential subtalar release in idiopathic CTEV (Manzone 1999). We were unable to draw a conclusion for this comparison as data from validated measures did not state when postoperative assessment was completed, and we were unable to obtain raw data. Relapse was noted in one patient (two feet) as a result of skin necrosis by the end of follow-up ( 27 months).

\section{Resistant Cases}

Four trials investigated treatment for resistant CTEV.

\section{Comparison 6: posteromedial soft tissue release versus subtalar} release

One trial compared posteromedial soft tissue release and subtalar release in children at an average age 5.9 months who had failed to respond to prior conservative treatment (Kaewpornsawan 2007). Children were excluded if associated syndromes were present. Prior treatment was not defined. We were unable to estimate a treatment effect as data from validated outcome measures were not available. Relapse was noted in both groups but data were not available to analyse.
Comparison 7: talocalcaneal interosseus ligament lengthening versus control during posteromedial soft tissue release surgery

One trial evaluated lengthening of the talocalcaneal interosseous ligament (TCIL) (El-Deeb 2007) in idiopathic severe or very severe (grade III or IV on Dimeglio scale) CTEV, which had failed repeated manipulation. We were unable to estimate a treatment effect as raw data were unavailable to re-analyse. Relapse was seen in both groups but data were not available to re-analyse. All relapses required surgical intervention.

Comparison 8: flexor hallucis longus and flexor digitorum longus lengthening versus simple decompression during surgery for toe flexion deformity in CTEV

One trial evaluated decompression versus lengthening of flexor hallucis longus and flexor digitorum longus in children (average age of 9.5 months) with CTEV with an average Pirani score of 5.5 (Lahoti 2008). Two syndromic feet were included (one in each group). Prior treatment was not defined. We were unable to estimate a treatment effect as data from validated outcome measures were not available. Three participants presented with hindfoot relapse by the end of follow-up (average four years); however, it was not stated if further treatment was required.

\section{Comparison 9: continuous passive motion (CPM) versus immobilisation in a cast post CTEV surgery}

One trial compared CPM versus immobilisation in a cast post CTEV surgery in children (average age of 8.2 months) after six months of failed manipulation and casting (Zeifang 2005). All children were classified as having severe CTEV (Dimeglio grade III). We were unable to estimate a treatment effect as data from validated outcome measures were not available. Relapse of one patient (cast group) with bilateral deformity occurred shortly after surgery and the participant was excluded; residual deformity in each group was noted at 48 months of follow-up. Further treatment was not documented.

\section{Relapsed cases}

No RCTs examined treatments for recurrent or relapsing CTEV.

\section{Neglected cases}

No RCTs examined treatments for neglected CTEV. 


\section{Other}

\section{Comparison 10: standard Ponseti technique versus an accelerated Ponseti technique}

One trial compared an accelerated Ponseti technique (cast changes three times per week) compared to the standard technique (weekly cast changes) in idiopathic CTEV (Harnett 2011). Published data included combined unilateral and bilateral cases. The author provided raw data on foot alignment (Pirani score), which could be re-analysed.
Participants were randomised into either standard Ponseti (21 participants, 32 feet) or accelerated Ponseti (19 participants, 29 feet). Analysis using a linear mixed model with random subject effects gave an estimated difference in mean total mean Pirani scores at follow-up of 0.311 ( $\mathrm{SE}=0.363,95 \% \mathrm{Cl}-0.399$ to 1.022 , Analysis 3.1, Figure 4). Using this model, the estimated correlation coefficient for left and right foot measurements in a group which received the same treatment was 0.8704$)$.

\section{Figure 4. Forest plot of comparison: 3 Standard Ponseti technique versus an accelerated Ponseti technique, outcome: 3.1 Pirani score at the end of serial plaster casting.}

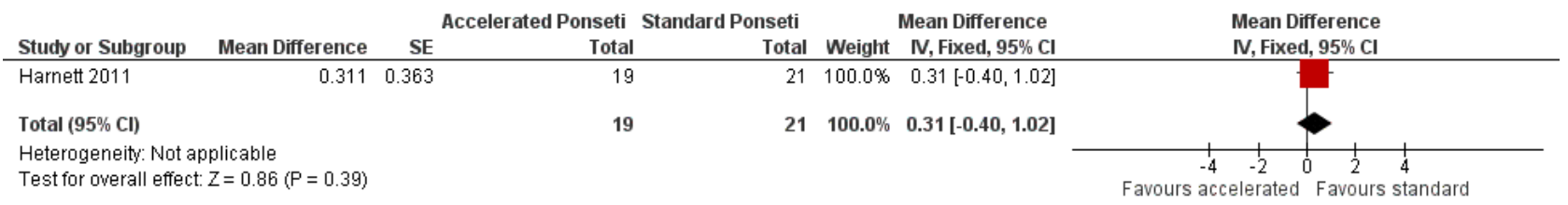

As the Pirani scores were highly skewed (not normally distributed), a bootstrap $\mathrm{Cl}$ was also constructed as a check on the robustness of these results. A non-parametric bootstrap (stratified by group, bilateral or unilateral status and clustered by subject) constructed from 100000 bootstrap samples gave a $95 \% \mathrm{Cl}$ extending from -0.201 to 0.863 ). Although this $\mathrm{Cl}$ is narrower than that reported above, the difference is still not statistically significant (Analysis 3.1, Figure 4).

In addition, it was reported that fewer plaster casts were required in the accelerated Ponseti group (Harnett 2011). No relapses occurred within six months.

\section{Comparison 11: Window versus Turco surgery}

One trial compared Window versus Turco surgery for idiopathic CTEV in children (mean age 9.6 months) with mild to moderate CTEV (Dimeglio grade I and II) (Siddiqui 2007). Pre-treatment was not defined. We were unable to estimate a treatment effect as data from validated outcome measures were not available. Relapse was reported in both groups but raw data were not available to reanalyse.

\section{DISCUSSION}

\section{Current research identified}

The treatment of CTEV continues to evolve. There are four distinct areas of therapeutic research: initial presentation, resistant deformity (after unsuccessful treatment), relapsed deformity (recurrence of deformity some time after initial satisfactory treatment) and neglected deformity (no early initial treatment). Within these categories two subgroups are recognised: idiopathic CTEV and syndromic CTEV. Since different presentations of CTEV were analysed separately using a variety of validated and nonvalidated outcome measures with diverse statistical approaches, we are unable to draw a single, overall conclusion regarding treatment for this condition.

\section{Study design \\ Inclusion and exclusion criteria}

Trials in which study design and inclusion criteria were not adequately described were not included. Rigid inclusion and exclusion criteria regarding prior treatment is essential to allow the reader to judge homogeneity of the participant population. Syndromic CTEV is known to be more resistant to treatment (Janicki 2009; Ponseti 2006) and may influence outcomes when combined with idiopathic cases. In relapsed cases, the treatment required may be influenced by the initial treatment prescribed (Halanski 2010a).

\section{Blinding}

No trials blinded participants. For trials where two surgical interventions were compared and postoperative care was identical in both groups, it is unlikely that participant (or carer) blinding would have affected the outcome because the care and compliance is virtually identical. Pittner 2008 compared semi-rigid (fibreglass) casting and plaster of Paris and Rijal 2010, Selmani 2012, Sud 2008 and Sanghvi 2009 compared Kite to Ponseti techniques of casting. It is unlikely that participant (or carer) blinding would have affected outcome in these cases because the care and compliance required by the participant is virtually identical. Siddiqui 2007 did not provide postoperative care details, therefore it is unknown if blinding may have affected bias.

\section{Dealing with bilateral and unilateral cases}

Inclusion criteria of one or both limbs per participant is a contentious issue in many fields, including foot and ankle orthopaedics (Bryant 2006; Perera 2007). Randomisation can occur at the participant or the limb level. When randomisation occurs at the participant level but feet in bilateral and unilateral cases are pooled, a unit of analysis error occurs. In bilateral cases each limb does not respond independently of the other and therefore violates the underlying independence assumption of statistical analysis. In cases where bilateral and unilateral cases are included, disproportionate weighting is given to the bilateral cases. For example, many treatments of CTEV involve participant compliance with bracing, such that if a participant with bilateral CTEV is non- 
compliant, two feet are affected by the one person. Including both feet from one participant may narrow $\mathrm{Cls}$ and overstate findings. Therefore, findings involving pooling of bilateral and unilateral cases should be interpreted with caution. Ten trials randomised participants (Cummings 2009; Harnett 2011; Kaewpornsawan 2007; Pittner 2008; Sanghvi 2009; Selmani 2012; Siddiqui 2007; Sud 2008; Zeifang 2005; Zwick 2009) and four trials randomised feet (El-Deeb 2007; Lahoti 2008; Manzone 1999; Rijal 2010). In bilateral cases all trials except one (Zeifang 2005) included all feet. Zeifang 2005 tossed a coin and only included one foot from each participant in their analysis.

Several options exist to overcome this issue. With raw data, post hoc statistical re-analysis of one limb per person can be performed (Lesaffre 2010; Perera 2007). During study design, randomisation by exclusion of the second limb or joint, randomly selecting one limb in bilateral cases, analysing bilateral cases as a distinct subgroup or stratifying bilateral and unilateral cases can be undertaken (Bryant 2006). Alternatively, statistical techniques, such as linear mixed models can be used.

Lahoti 2008 randomly allocated each foot to a different intervention. In bilateral cases where each foot is randomly assigned to a different treatment, there is less variation between individuals, allowing a more precise estimation of the treatment effect. However, the analysis of bilateral cases where each foot receives a different intervention still requires an appropriate statistical analysis to account for any potential within-participant correlation.

\section{Outcomes}

\section{Function and quality of life}

Function was an outcome in six trials (El-Deeb 2007; Kaewpornsawan 2007; Manzone 1999; Sanghvi 2009; Sud 2008; Zwick 2009) with one using a validated scale (Zwick 2009). However, this trial combined bilateral and unilateral cases and raw data were not available to appropriately re-analyse. Valid assessment of function is required as part of CTEV assessment as routine objective measures for CTEV (for example, $x$-ray) do not reliably correlate with function (Farsetti 2006; Fridman 2007; Kuo 2001; Vitale 2005).

Generic health-related quality of life was also assessed by Zwick 2009 using the validated PODCl. Currently no conditionspecific quality of life instrument has been validated for CTEV. In the future, quality of life assessment might provide further information, particularly in cases where treatment requires longterm compliance with bracing or rehabilitation after surgery.

\section{Foot alignment}

Foot alignment was assessed in all trials. Ten trials used validated outcome measures (El-Deeb 2007; Harnett 2011; Lahoti 2008; Manzone 1999; Pittner 2008; Sanghvi 2009; Selmani 2012; Rijal 2010; Zeifang 2005; Zwick 2009). As CTEV deformity occurs in several planes of movement (Ponseti 2005), assessment of foot alignment using valid scales is essential to report on all aspects of the deformity. Poor foot alignment correlates with the requirement for further intervention.

\section{Reporting on compliance}

Compliance was not formally assessed in any of the included trials. In five trials, different regimes of bracing and postoperative care requiring parent or carer compliance were required (Sanghvi 2009; Selmani 2012; Sud 2008; Zeifang 2005; Zwick 2009). Four trials recorded compliance through communication with parents (Cummings 2009; Sud 2008; Zeifang 2005; Zwick 2009). Accurate assessment of compliance was noted as a limitation in two trials (Selmani 2012; Zeifang 2005). Cummings 2009 was unable to demonstrate an association between compliance and rate of relapse. Compliance with bracing has been shown to influence the rate of relapse (Haft 2007; Morcuende 2004). However, compliance with bracing is very difficult to assess objectively and no reliable and valid method has been reported.

\section{Reporting on relapse}

Thirteen trials reported on relapse (Cummings 2009; El-Deeb 2007; Harnett 2011; Kaewpornsawan 2007; Lahoti 2008; Manzone 1999; Rijal 2010; Sanghvi 2009; Selmani 2012; Siddiqui 2007; Sud 2008; Zeifang 2005; Zwick 2009); however, no trial defined relapse in their initial protocol. Many factors define relapse, making it difficult to report on. There is emerging literature attempting to discriminate relapse from mild resistant deformity (Halanski 2010b). In CTEV, a relapse can include multiple deformities, for example, equinus (tightness of the heel), adductus (in-turning of the foot) or cavus (high arch). Therefore, the treatment to correct relapse can be an indication of the severity of the deformity. A summary of reported relapse is provided in Table 4.

Two main types of relapse are recognised: passive and dynamic (or residual). Passive relapse refers to a loss in range of movement, whereas dynamic refers to a positional relapse where passive range is still present. Dynamic relapse, if left untreated, can lead to a passive relapse (Ponseti 2005). Treatment options depend on the type of relapse (Farsetti 2006; Haft 2007; Nogueira 2009; Ponseti 2005). A well defined outcome measure of relapsed cases will allow the reader to determine the long-term outcome of the initial treatment.

\section{Cost-benefit analysis}

One trial has examined the cost-effectiveness of Ponseti versus primary surgical management for initial treatment of idiopathic CTEV in 55 participants (86 feet) in the New Zealand socialised healthcare system (Halanski 2009). Initially designed as an RCT, only nine participants agreed to randomisation, with the remainder choosing their treatment path. Cost analysis was divided into four groups: unilateral CTEV total cost, bilateral CTEV total cost, unilateral CTEV with recurrence total cost and bilateral CTEV with recurrence total cost. Secondary outcome measures of number of clinic visits, days in hospital, number of visits to operating theatres, operating room time, antibiotic doses and pain medication doses were also examined.

During the average follow-up period of 3.5 years, total cost of treatment per foot was significantly less in the Ponseti group for unilateral CTEV, bilateral CTEV and bilateral CTEV with recurrence. Total cost was not significantly different between groups for unilateral CTEV with recurrence. Furthermore, the surgical group required a greater average number of days in hospital and doses of pain medication.

This trial also calculated the equivalent cost of the above treatment in the United States healthcare system, reporting significantly higher costs in the surgical arm for unilateral CTEV, bilateral CTEV and unilateral CTEV with recurrence. 


\section{Summary of main results}

\section{Initial cases}

Eight trials evaluated initial presentations of CTEV. One trial found the Ponseti technique to produce significantly better foot alignment at the end of serial casting compared to the Kite technique. Adverse events were not reported. Correction of relapse following Ponseti treatment required major foot surgery less often than relapse after Kite treatment. Another trial found the Ponseti technique to be superior to a traditional technique (plaster casting followed by major foot surgery). This trial had small numbers as a formal stopping rule was activated after the Kite technique was observed to lead to higher rates of major surgery than the Ponseti technique. No conclusions could be drawn for other interventions: surgery; modification of the Ponseti technique through the use of different plaster casting products (plaster of Paris versus semirigid casting); or the addition of botulinum toxin A to the Ponseti technique. The reporting of adverse events was limited in all trials. In those involving serial casting (plaster casting) adverse events included pressure areas, cast slippage and skin irritations.

\section{Resistant cases}

All trials evaluating resistant cases involved major surgical procedures or postoperative care (for example CPM). No conclusions could be drawn with the data available. All relapses required major surgical intervention to correct any recurrent deformity.

\section{Other cases}

One trial concluded that the accelerated Ponseti technique (cast changes three times per week) was as effective as the standard Ponseti technique (weekly cast changes). No conclusions could be drawn for two surgical procedures (Window versus Turco procedures) due to limited available data, but wound infections were reported to be higher in the Turco group (20\% versus $3 \%$ ) as were wound dehiscence (opening), skin necrosis (7\%) and scarring and fibrosis (10\%).

\section{Relapsed cases}

No conclusions could be drawn for recurrent cases.

\section{Neglected cases}

No conclusions could be drawn for neglected cases.

\section{Overall completeness and applicability of evidence}

There are limitations to this review. This review includes RCTs and quasi-RCTs. Due to ethical considerations, most trials investigating treatment of CTEV are not RCTs but comparisons of treatments which have been selected by the parent, carer or clinician. Inclusion of these additional trials may have allowed further analysis, however the lack of randomisation would have introduced significant bias.

\section{Quality of the evidence}

\section{Limitations of available evidence}

It is clear that well powered long-term RCTs are needed. While there is limited evidence of the Ponseti technique providing superior short-term results to other techniques, long-term observational studies (30 to 45 years) suggest that the Ponseti technique reduces the need for major foot surgery (surgery involving joints) (Morcuende 2004; Zionts 2010) and is more likely to lead to a painfree foot in adulthood (Cooper 1995; Ippolito 2003). Many studies did not comment on adverse events. Therefore analysis of adverse events could not be undertaken due to lack of data.

The evidence base for treatment of CTEV remains incomplete. Many clinically important aspects of care have not been evaluated in RCTs. The following list identifies some of the evidence gaps in the current body of literature.

- Comparison of different conservative techniques for the treatment of resistant CTEV.

- Treatment of participants with relapsed (recurrent) CTEV (those who have undergone prior treatment with satisfactory results and present with recurrence of the deformity).

- Treatment of non-idiopathic CTEV (for example atypical or complex CTEV, or CTEV associated with syndromes).

- Treatment of neglected CTEV.

\section{Potential biases in the review process}

\section{Locating relevant trials}

We identified all the trials in this review through electronic searching. All were published in English-language journals. Although we made efforts to identify trials reported in languages other than English and considered some papers for possible inclusion, they did not meet our criteria. We are reasonably confident that we identified all relevant trials because RCTs in CTEV are rare and therefore typically published.

\section{Agreements and disagreements with other studies or reviews}

To date there have been no other systematic reviews of RCTs of interventions for CTEV.

\section{AUTHORS' CONCLUSIONS}

\section{Implications for practice}

Few randomised controlled trials exist evaluating the various presentations of congenital talipes equinovarus and they provide limited evidence on which to base clinical decisions. Evidence is accumulating, but small sample sizes and the limited use of validated outcome measures limit clear conclusions.

In initial cases, the main findings from this review based on the evidence from randomised controlled trials are as follows.

- The Ponseti technique produced significantly better foot alignment in the short term compared to the Kite technique, based on low quality evidence. While relapse rates were similar between groups, the participants in the Ponseti group less often required major surgery to correct relapse.

- The Ponseti technique produced significantly better foot alignment in the short term compared to a traditional technique. The quality of this evidence was very low.

There was a further finding in other cases (it was not stated if a prior intervention had taken place). 
- One trial showed no statistically significant difference in the effectiveness of an standard Ponseti technique compared with an accelerated technique. This evidence was of moderate quality.

\section{Implications for research}

To develop a strong evidence base for the treatment of various presentations of congenital talipes equinovarus, there needs to be further evaluation in well designed randomised controlled trials. However, observational studies (Cooper 1995; Ippolito 2003) have shown the Ponseti technique to produce superior long-term (30to 45-year) results compared to major foot surgery. Randomisation may be considered unethical in certain circumstances and well designed controlled trials may provide more opportunities to analyse different treatments. The following measures would improve the quality of future trials assessing interventions for congenital talipes equinovarus: ensuring baseline comparability by detailed inclusion and exclusion criteria; employing the use of valid and reliable outcome measures for function and quality of life; investigating robust methods to measure compliance; evaluation of treatment for relapsed and neglected cases and those with nonidiopathic congenital talipes equinovarus. Consideration must also be given to statistical analysis, particularly when pooling unilateral and bilateral cases.

\section{ACKNOWLEDGEMENTS}

The reviewers would like to thank the editorial team of the Cochrane Neuromuscular group, particularly Dr Ros Quinlivan and Ms Ruth Brassington for their assistance in preparing this review; Ms Angela Gunn for assisting in developing the search strategy and conducting searching of electronic databases; and Chris Frost (an author on the first version of the review) and Elizabeth Barnes for statistical support. Thank you to Kristy Rose and Tamis Pin for assistance with translation of articles and Ms Trish Bennett for assistance with the PEDro search. Finally the review authors would like to thank the authors of included trials who responded to requests for additional information/data: Dr Paul Harnett (UK), Dr Ernst Zwick (Austria), Dr Amish Sanghvi (India), Dr Raju Rijal (Nepal), Dr Kevin Klingele (USA), Dr Hanneke Andriesse (Sweden), Dr Khaled El-Adwar (Egypt) and Mr Om Lahoti (UK).

Editorial support from the Cochrane Neuromuscular Disease Group is funded by the MRC Centre for Neuromuscular Diseases and the Muscular Dystrophy Campaign. 


\section{RE F E R E N C E S}

\section{References to studies included in this review}

Cummings 2009 \{published data only\}

Cummings RJ. The effectiveness of botulinum A toxin as an adjunct to the treatment of clubfeet by the Ponseti method: a randomized, double blind, placebo controlled study. Journal of Pediatric Orthopaedics 2009;29(6):564-9. [PUBMED: 19700984]

El-Deeb 2007 \{published data only (unpublished sought but not used)\}

* El-Deeb KH, Ghoneim AS, El-Adwar KL, Khalil AA. Is it hazardous or mandatory to release the talocalcaneal interosseous ligament in clubfoot surgery?: a preliminary report. Journal of Pediatric Orthopaedics 2007;27(5):517-21. [PUBMED: 17585259]

\section{Harnett 2011 \{published and unpublished data\}}

Harnett P, Freeman R, Harrison WJ, Brown LC, Backles V. An accelerated Ponseti versus the standard Ponseti method: a prospective randomised controlled trial. The Journal of Bone and Joint Surgery. British Volume 2011;93-B(3):404-8. [DOI: 10.1302/0301-620X.93B3; PUBMED: 21357965]

\section{Kaewpornsawan 2007 \{published data only\}}

Kaewpornsawan K, Khuntisuk S, Jatunarapit R. Comparison of modified posteromedial release and complete subtalar release in resistant congenital clubfoot: a randomized controlled trial. Journal of the Medical Association of Thailand 2007;90(5):936-41. [PUBMED: 17596049]

\section{Lahoti 2008 \{published and unpublished data\}}

* Lahoti O, Bajaj S. Is there a role for lengthening flexor hallucis and flexor digitorum longus tendons in surgery for club foot?: a preliminary report. The Journal of Bone and Joint Surgery. British Volume 2008;90-B(6):801-2. [PUBMED: 18539675]

\section{Manzone 1999 \{published data only\}}

Manzone P. Clubfoot surgical treatment: preliminary results of a prospective comparative study of two techniques. Journal of Pediatric Orthopaedics Part B 1999;8(4):246-50. [PUBMED: 10513357]

Pittner 2008 \{published data only (unpublished sought but not used)\}

* Pittner DE, Klingele KE, Beebe AC. Treatment of clubfoot with the Ponseti method: a comparison of casting materials. Journal of Pediatric Orthopaedics 2008;28(2):250-3. [PUBMED: 18388724]

Rijal 2010 \{published data only (unpublished sought but not used)\} Rijal R, Shrestha BP, Singh GK, Singh M, Nepal P, Khanal GP, et al. Comparison of Ponseti and Kite's method of treatment for idiopathic clubfoot. Indian Journal of Orthopaedics 2010;44(2):202-7. [PUBMED: 20419009]
Sanghvi 2009 \{published data only (unpublished sought but not used)\}

Sanghvi AV, Mittal VK. Conservative management of idiopathic clubfoot: Kite versus Ponseti method. Journal of Orthopaedic Surgery (Hong Kong) 2009;17(1):67-71. [PUBMED: 19398797]

Selmani 2012 \{published data only (unpublished sought but not used)\}

Selmani E. Is Ponseti's method superior to Kite's for clubfoot treatment he?. European Orthopaedics and Traumatology 2012;3(3):183-7. [EMBASE: 2013159837]

\section{Siddiqui 2007 \{published data only\}}

Siddiqui MA, Pirwani MA, Bhura S, Soomro YH. Window procedure versus Turco procedure for the treatment of talipes equino varus. Pakistan Journal of Surgery 2007;23(3):212-6.

\section{Sud 2008 \{published data only\}}

Sud A, Tiwari A, Sharma D, Kapoor S. Ponseti's vs. Kite's method in the treatment of clubfoot - a prospective randomised study. International Orthopaedics 2008;32(3):409-13. [PUBMED: 17323092]

\section{Zeifang 2005 \{published data only\}}

Zeifang F, Carstens C, Schneider S, Thomsen M. Continuous passive motion versus immobilisation in a cast after surgical treatment of idiopathic club foot in infants: a prospective, blinded, randomised clinical study. Journal of Bone and Joint Surgery. British Volume 2005;87-B(12):1663-5. [PUBMED: 16326882]

Zwick 2009 \{published data only (unpublished sought but not used)\}

Zwick EB, Kraus T, Maizen C, Steinwender G, Linhart WE. Comparison of Ponseti versus surgical treatment for idiopathic clubfoot: a short- term preliminary report. Clinical Orthopaedics and Related Research 2009;467(10):2668-76. [DOI: 10.1007/ s11999-009-0819-5; PUBMED: 19350335]

\section{References to studies excluded from this review}

Andriesse 2008 \{published data only\}

Andriesse H, Hägglund G. Comparison of serial casting and stretching technique in children with congenital idiopathic clubfoot. Evaluation of a new system. Acta Orthopaedica 2008;79(1):53-61.

\section{Atar 1993 \{published data only\}}

Atar D, Lehman WB, Grant AD. Complete soft-tissue clubfoot release with and without internal fixation. Orthopaedic Review 1993;22(9):1015-6.

\section{Aurell 2005 \{published data only\}}

Aurell Y, Andriesse H, Johansson A, Jonsson K. Ultrasound assessment of early clubfoot treatment: a comparison of the Ponseti method and a modified Copenhagen method. Journal of Pediatric Orthopaedics, Part B 2005;14(5):347-57. 
Chang 1991 \{published data only\}

Chang YL, Huang SC, Liu TK. Surgical management of resistant idiopathic congenital clubfoot. Journal of the Formosan Medical Association 1991;90(12):1186-93.

\section{DePuy 1989 \{published data only\}}

DePuy J, Drennan JC. Correction of idiopathic clubfoot: a comparison of results of early versus delayed posteromedial release. Journal of Pediatric Orthopedics 1989;9(1):44-8.

\section{DeRosa 1986 \{published data only\}}

DeRosa GP, Stepro D. Results of posteromedial release for the resistant clubfoot. Journal of Pediatric Orthopedics 1986;6(5):590-5.

\section{Dimeglio 1996 \{published data only\}}

Dimégio A, Bonnet F, Mazeau P, De Rosa V. Orthopaedic treatment and passive motion machine: consequences for the surgical treatment of clubfoot. Journal of Pediatric Orthopaedics Part B 1996;5(3):173-80.

\section{Doğan 2002 \{published data only\}}

Doğan A, Bagatur AE, Zorer G. The effect of deep deltoid ligament release on dorsiflexion in congenital clubfoot treated with complete subtalar release. Acta Orthopaedica et Traumatologica Turcica 2002;36(3):248-55.

\section{Farsetti 2009 \{published data only\}}

Farsetti P, De Maio F, Russolillo L, Ippolito E. CT study on the effect of different treatment protocols for clubfoot pathology. Clinical Orthopaedics and Related Research 2009;467(5):1243-9.

Faulks 2009 \{published data only\}

Faulks S, Richards BS. Clubfoot treatment: Ponseti and French functional methods are equally effective. Clinical Orthopaedics and Related Research 2009;467(5):1278-82.

\section{Halanski 2010 \{published data only\}}

Halanski MA, Davison JE, Huang JC, Walker CG, Walsh SJ, Crawford HA. Ponseti method compared with surgical treatment of clubfoot: a prospective comparison. Journal of Bone and Joint Surgery. American Volume 2010;92(2):270-8.

\section{Ippolito 2003 \{published data only\}}

Ippolito E, Farsetti P, Caterini R, Tudisco C. Long-term comparative results in patients with congenital clubfoot treated with two different protocols. Journal of Bone and Joint Surgery. American Volume 2003;85-A(7):1286-94

\section{Janicki 2011 \{published data only\}}

Janicki JA, Wright JG, Weir S, Narayanan UG. A comparison of ankle foot orthoses with foot abduction orthoses to prevent recurrence following correction of idiopathic clubfoot by the Ponseti method. Journal of Bone and Joint Surgery. British Volume 2011;93-B(5):700-4.

\section{Kesemenli 2003 \{published data only\}}

Kesemenli CC, Kapukaya A, Subaşi M, Necmioglu S, Arslan H, Ozbag D, et al. Anthropometric study of patients treated for clubfoot. Journal of Pediatric Orthopedics 2003;23(4):498-502.

\section{Kuo 2001 \{published data only\}}

Kuo KN, Hennigan SP, Hastings ME. Anterior tibial tendon transfer in residual dynamic clubfoot deformity. Journal of Pediatric Orthopedics 2001;21(1):35-41.

\section{Li 2007 \{published data only\}}

Li L, Zhang L, Wang E. Comparison of long-term results between muscle-strength balancing procedure and McKay procedure in treating congenital clubfoot. Chinese Journal of Reparative and Reconstructive Surgery 2007;21(10):1108-12.

\section{Miura 2005 \{published data only\}}

Miura Y, Kamegaya M, Saisu T, Moriya H. Effect of postoperative early ankle motion exercise using hinged ankle-foot orthoses in clubfoot. Journal of Pediatric Orthopedics 2005;25(4):529-32.

Napiontek 2000 \{published data only\}

Napiontek M. Muscular strength after extensive operative treatment of congenital talipes equinovarus. Journal of Pediatric Orthopaedics, Part B 2000;9(2):128-36.

Narang 2011 \{published data only\}

Narang AS, Singh H, Sharma V, Khare S. Comparison of short term results of JESS distractor and one stage posteriomedial release for neglected, resistant and relapsed or recurrent club foot. Journal of Orthopaedics 2011;8(4):e8.

Nilgün 2011 \{published data only\}

Nilgün B, Suat E, Engin Şí, Fatma U, Yakut Y. Short-term results of intensive physiotherapy in clubfoot deformity treated with the Ponseti method. Pediatrics International 2011;53(3):381-5.

O'Brien 2004 \{published data only\}

O'Brien SE, Karol LA, Johnston CE 2nd. Calcaneus gait following treatment for clubfoot: preliminary results of surgical correction. Journal of Pediatric Orthopaedics, Part $B$ 2004;13(1):43-7.

Ponseti 2006 \{published data only\}

Ponseti IV, Zhivkov M, Davis N, Sinclair M, Dobbs MB, Morcuende JA. Treatment of the complex idiopathic clubfoot. Clinical Orthopaedics and Related Research 2006;451:171-6.

Richards 2008 \{published data only\}

Richards BS, Faulks S, Rathjen KE, Karol LA, Johnston CB, Jones SA. A comparison of two nonoperative methods of idiopathic clubfoot correction: the Ponseti method and the French functional (physiotherapy) method. Journal of Bone and Joint Surgery. American Volume 2008;90(11):2313-21.

\section{Simons 1985 \{published data only\}}

Simons GW. Complete subtalar release in club feet. Part II Comparison with less extensive procedures. Journal of Bone and Joint Surgery. American Volume 1985;67(7):1056-65.

\section{Steinman 2009 \{published data only\}}

Steinman S, Richards BS, Faulks S, Kaipus K. A comparison of two nonoperative methods of idiopathic clubfoot correction: the Ponseti method and the French functional (physiotherapy) method. Surgical technique. Journal of Bone and Joint Surgery. American Volume 2009;91(Suppl 2):299-312. 
Thompson 1982 \{published data only\}

Thompson GH, Richardson AB, Westin GW. Surgical management of resistant congenital talipes equinovarus deformities. Journal of Bone and Joint Surgery. American Volume 1982;64(5):562-65.

\section{Tschopp 2002 \{published data only\}}

Tschopp O, Rombouts JJ, Rossillon R. Comparison of posteromedial and subtalar release in surgical treatment of resistant clubfoot. Orthopedics 2002;25(5):527-9.

\section{Uglow 2000 \{published data only\}}

Uglow MG, Clarke NM. The functional outcome of staged surgery for the correction of talipes equinovarus. Journal of Pediatric Orthopedics 2000;20(4):517-23.

\section{Xu 2011 \{published data only\}}

Xu RJ. A modified Ponseti method for the treatment of idiopathic clubfoot: a preliminary report. Journal of Pediatric Orthopedics 2011;31(3):317-9.

\section{References to ongoing studies}

\section{NCT01067651 \{published data only\}}

NCT01067651. Comparison of two different cast materials for the treatment of congenital idiopathic clubfoot using the Ponseti method: a prospective randomized controlled trial. http://clinicaltrials.gov/ct2/show/NCT01067651 (accessed 27 November 2013).

\section{Additional references}

\section{Alvarez 2005}

Alvarez CM, Tredwell SJ, Keenan SP, Beauchamp RD, Choit RL, Sawatzky BJ, et al. Treatment of idiopathic clubfoot utilizing botulinum A toxin: a new method and its short-term outcomes. Journal of Pediatric Orthopaedics 2005;25(2):229-35.

\section{Bryant 2006}

Bryant D, Havey TC, Roberts R, Guyatt G. How many patients? How many limbs? Analysis of the patients or limbs in the orthopaedic literature: a systematic review. The Journal of Bone and Joint Surgery 2006;88(1):41-5. [DOI: 10.2106/JBJS.E.00272]

\section{Cooper 1995}

Cooper DM, Dietz FR. Treatment of idiopathic clubfoot. A thirty year follow-up note. Journal of Bone and Joint Surgery. American Volume 1995;77-A(10):1447-89.

\section{Cusick 1990}

Cusick B. Serial casts: their use in the management of spasticityinduced foot deformity. Tuscon, Arizona: Communication Skill Builders, 1990

\section{De Gheldere 2008}

De Gheldere A, Docquier PL. Analytical radiography of clubfoot after tenotomy. Journal of Pediatric Orthopaedics 2008;28(6):691-4.

\section{Dietz 2006}

Dietz FR. Treatment of a recurrent clubfoot deformity after initial correction with the Ponseti technique. Instructional Course Lectures 2006; Vol. 55:625-9.

\section{Dietz 2009}

Dietz FR, Tyler MC, Leary KS, Damiano PC. Evaluation of a disease-specific instrument for idiopathic clubfoot outcome. Clinical Orthopaedics and Related Research 2009;467(5):1256-62.

\section{Diméglio 1995}

Diméglio A, Bensahel H, Souchet P, Mazeau P, Bonnet F. Classification of clubfoot. Journal of Pediatric Orthopaedics. Part B 1995;4(2):129-36.

\section{Dobbs 2000}

Dobbs MB, Morcuende JA, Gurnett CA, Ponseti IV. Treatment of idiopathic clubfoot: an historical review. lowa Orthopaedic Journal 2000;20:59-64.

\section{Dobbs 2006}

Dobbs MB, Nunley R, Schoenecker PL. Long-term follow-up of patients with clubfeet treated with extensive soft-tissue release. Journal of Bone and Joint Surgery. American Volume 2006;88(5):986-96.

\section{Dobbs 2009}

Dobbs M, Gurnett CA. Update on clubfoot: etiology and treatment. Clinical Orthopaedics and Related Research 2009;467(5):1146-53. [DOI: 10.1007/s11999-009-0734-9]

\section{Farsetti 2006}

Farsetti P, Caterini R, Mancini F, Potenza V, Ippolito E. Anterior tibial tendon transfer in relapsing congenital clubfoot: longterm follow-up study of two series treated with a different protocol. Journal of Pediatric Orthopaedics 2006;26(1):83-90.

\section{Fridman 2007}

Fridman MW, de Almeida Fialho HS. The role of radiographic measurements in the evaluation of congenital clubfoot surgical results. Skeletal Radiology 2007;36(2):129-38.

\section{Graf 2010}

Graf A, Hassani S, Krzak J, Long J, Caudill A, Flanagan A, et al. Long-term outcome evaluation in young adults following clubfoot surgical release. Journal of Pediatric Orthopaedics 2010;30(4):379-85

\section{Haft 2007}

Haft GF, Walker CG, Crawford HA. Early clubfoot recurrence after use of the Ponseti method in a New Zealand population. Journal of Bone and Joint Surgery. American Volume 2007;89A(3):487-93.

\section{Halanski 2009}

Halanski MA, Huang JC, Walsh SJ, Crawford HA. Resource utilization in clubfoot management. Clinical Orthopaedics and Related Research 2009;5:1171-9. Erratum in: Clinical Orthopedics and Related Research 2010 Apr;468(4):1186. 


\section{Halanski 2010a}

Halanksi MA, Davison JE, Huang JC, Walker CG, Walsh SJ, Crawford HA. Ponseti method compared with surgical treatment of clubfoot: a prospective comparison. Journal of Bone and Joint Surgery. American Volume 2010;92(2):270-8. [DOI: 10.2106/JBJS.H.01560]

\section{Halanski 2010b}

Halanski MA, Maples DL, Davison JE, Huang JC, Crawford HA. Separating the chicken from the egg: an attempt to discern between clubfoot recurrences and incomplete corrections. lowa Orthopaedic Journal 2010;20:29-34. [21045968]

\section{Handelsman 1982}

Handelsman JE, Badalamente MA. Club foot: a neuromuscular disease. Developmental Medicine and Child Neurology 1982;24(1):3-12.

\section{Hester 2009}

Hester TW, Parkinson LC, Robson J, Misra S, Sangha H, Martin JE. A hypothesis and model of reduced fetal movement as a common pathogenetic mechanism in clubfoot. Medical Hypotheses 2009;73(6):986-8.

\section{Higgins 2008}

Higgins JPT, Green S (editors). Cochrane Handbook for Systematic Reviews of Interventions. Chichester (UK): John Wiley \& Sons, 2008.

\section{Higgins 2008b}

Sterne JAC, Egger M, Moher D. Chapter 10: Addressing reporting biases. In: Higgins JPT, Green S editor(s). Cochrane Handbook for Systematic Reviews of Interventions. Chichester (UK): John Wiley \& Sons, 2008.

\section{Higgins 2008c}

Higgins JPT, Deeks JJ. Chapter 7: Selecting studies and collecting data. In: Higgins JPT, Green S editor(s). Cochrane Handbook for Systematic Reviews of Interventions. Chichester (UK): John Wiley \& Sons, 2008.

\section{Higgins 2011}

Higgins JPT, Green S (editors). Cochrane Handbook for Systematic Reviews of Interventions Version 5.1.0 [updated March 2011]. The Cochrane Collaboration, 2011. Available from www.cochrane-handbook.org.

\section{Janicki 2009}

Janicki JA, Narayanan UG, Harvey B, Roy A, Ramseier LE, Wright JG. Treatment of neuromuscular and syndromeassociated (nonidiopathic) clubfeet using the Ponseti method. Journal of Pediatric Orthopaedics 2009;29(4):393-7.

\section{Keret 2002}

Keret D, Ezra E, Lokiec F, Hayek S, Segev E, Wientroub S. Efficacy of prenatal ultrasonography in confirmed club foot. Journal of Bone and Joint Surgery. British Volume 2002;84(7):1015-9.

\section{Kite 1972}

Kite JH. Non operative treatment of congenital clubfoot. Clinical Orthopaedics and Related Research 1972;84:29-38.

\section{Laaveg 1980}

Laaveg SJ, Ponseti IV. Long-term results of treatment of congenital club foot. Journal of Bone and Joint Surgery. American Volume 1980;62(1):23-31.

\section{Landgraf 1999}

Landgraf JM, Abetz L, Ware JE. The Child Health Questionnaire (CHQ): A User's Manual (2nd printing). Boston, MA: HealthAct, 1999.

\section{Lesaffre 2010}

Lesaffre E, Philstrom B, Needleman I, Worthington $\mathrm{H}$. The design and analysis of split-mouth studies: what statisticians and clinicians should know. Statistics in Medicine 2009;28(28):3470-82. [DOI: 10.1002/sim.3634]

\section{Lovell 1979}

Lovell WW, Farley D. Treatment of congenital clubfoot. Ona Journal 1979;6(11):453-6.

\section{Lovell 2007}

Lovell ME, Morcuende JA. Neuromuscular disease as the cause of late clubfoot relapses: report of 4 cases. Iowa Orthopaedic Journal 2007;27:82-4.

\section{Masrouha 2012}

Masrouha KZ, Morcuende JA. Relapse after tibialis anterior tendon transfer in idiopathic clubfoot treated by the Ponseti method. Journal of Pediatric Orthopedics 2012;32(1):81-4.

\section{Morcuende 2004}

Morcuende JA, Dolan LA, Dietz FR, Ponseti IV. Radical reduction in the rate of extensive corrective surgery for clubfoot using the Ponseti method. Pediatrics 2004;113(2):376-80.

\section{Nogueira 2009}

Nogueira MP, Ey Batlle AM, Alves CG. Is it possible to treat recurrent clubfoot with the Ponseti technique after posteromedial release?. Clinical Orthopaedics and Related Research 2009;467(5):1298-305. [DOI: 10.1007/ s11999-009-0718-9]

\section{Perera 2007}

Perera R, Glasziou P. A simple method to correct for the design effect in systematic review of trials using paired dichotomous data. Journal of Clinical Epidemiology 2007;60(9):975-8. [DOI: 10.1016/j.jclinepi.2006.12.004]

\section{Pirani 2001}

Pirani S, Zeznik L, Hodges D. Magnetic resonance imaging study of the congenital clubfoot treated with the Ponseti method. Journal of Pediatric Orthopaedics 2001;21(6):719-26.

\section{Pirani 2008}

Pirani S, Hodges D, Sekeramayi F. A reliable and valid method of assessing the amount of deformity in the congenital clubfoot deformity. The Journal of Bone and Joint Surgery. British Volume 2008;90-B(Supp I ) : 53 . 


\section{Ponseti 2005}

Ponseti I, Morcuende J, Mosca V, Pirani S, Dietz F, Herzenberg J, et al. Clubfoot: Ponseti Management. 2nd Edition. Global-HELP Organization, 2005.

\section{Radler 2007}

Radler C, Manner HM, Suda R, Burghardt R, Herzenberg JE, Ganger R, et al. Radiographic evaluation of idiopathic clubfeet undergoing Ponseti treatment. Journal of Bone and Joint Surgery. American Volume 2007;89(6):1177-83.

\section{Redmond 2006}

Redmond AC, Crosbie J, Ourvrier RA. Development and validation of a novel rating system for scoring standing foot posture: the Foot Posture Index. Clinical Biomechanics 2006;21(1):89-98.

\section{RevMan 2008 [Computer program]}

The Nordic Cochrane Centre, The Cochrane Collaboration. Review Manager (RevMan). Version 5.0. Copenhagen: The Nordic Cochrane Centre, The Cochrane Collaboration, 2008.

\section{Richards 2007}

Richards BS, Dempsey M. Magnetic resonance imaging of the congenital clubfoot treated with the French functional (physical therapy) method. Journal of Pediatric Orthopaedics 2007;27(2):214-9.

\section{Sud 2007}

Sud A, Tiwari A, Sharma D, Kapoor S. Ponseti's vs. Kite's method in the treatment of clubfoot - a prospective randomised study. International Orthopaedics 2008;32(3):409-13.

\section{CHARACTERISTICS OF STUDIES}

Characteristics of included studies [ordered by study ID]

\section{Vitale 2005}

Vitale MG, Choe JC, Vitale MA, Lee FY, Hyman JE, Roye DP Jr. Patient-based outcomes following clubfoot surgery: a 16year follow-up study. Journal of Pediatric Orthopaedics 2005;25(4):533-8.

\section{Ware 1992}

Ware JE Jr, Sherbourne CD. The MOS 36-item short-form health survey (SF-36). Conceptual framework and item selection. Medical Care 1992;30(6):473-83.

\section{Zionts 2010}

Zionts LE, Zhao G, Hitchcock K, Maewal J, Ebramzadeh E. Has the rate of extensive surgery to treat idiopathic clubfoot declined in the United States?. Journal of Bone and Joint Surgery. American Volume 2010;92(4):882-9.

\section{References to other published versions of this review Gray 2010}

Gray K, Pacey V, Gibbons P, Little D, Burns J. Interventions for congenital talipes equinovarus. Cochrane Database of Systematic Reviews 2010, Issue 7. [DOI: 10.1002/14651858.CD008602]

\section{Gray 2012}

Gray K, Pacey V, Gibbons P, Little D, Frost C, Burns J. Interventions for congenital talipes equinovarus (clubfoot). Cochrane Database of Systematic Reviews 2012, Issue 4. [DOI: 10.1002/14651858.CD008602.pub2]

* Indicates the major publication for the study

Cummings 2009

\begin{tabular}{ll}
\hline Methods & RCT. Two-arm parallel-group design \\
\hline Participants & 20 participants with 32 CTEV feet who presented to a single centre \\
Inclusion criteria: full-term infants aged 0 to 30 days, with CTEV Dimeglio grade III \\
Exclusion criteria: none stated \\
PARTICIPANT CHARACTERISTICS \\
Age: birth to 30 days \\
Sex male (\%): $60 \%$ \\
Botulinium toxin A group \\
Characteristics of feet: 17 feet. 3 right, 2 left, 6 bilateral \\
Placebo group \\
Characteristics of feet: 15 feet. 2 right, 1 left, 6 bilateral \\
\end{tabular}


Cummings 2009 (Continued)

Interventions

Botulinum toxin A versus placebo

Randomisation of participants (not feet)

Both botulinum toxin $A$ and placebo solutions manufactured and placed in identical vials by the manufacturer. Vials were coded by the manufacturer. A pharmacist at the centre randomly chose a vial and delivered it to the neurology clinic

Gastrocnemius and tibialis posterior muscles were injected under EMG (electromyography, a technique which records activity in muscles) guidance by a paediatric neurologist prior to initiation of serial casting using the Ponseti technique

After the foot deformity was corrected (heel varus $\geq$ neutral; forefoot adduction $\geq$ neutral; dorsiflexion $\geq$ $15^{\circ}$ ) feet were braced in reverse last shoes attached to an abduction orthosis set at $70^{\circ}$

Feet that were not corrected with casting alone underwent a percutaneous Achilles tenotomy under local anaesthetic followed by further serial casting, until corrected

Follow-up average: 27 months (15 months to 4 years)

\begin{tabular}{ll}
\hline Outcomes & Time in cast for correction \\
Need for Achilles tenotomy \\
Relapse rate \\
Treatment required for correction of relapse
\end{tabular}

Notes

This study did not state if children with syndromal CTEV were included or excluded

\section{Risk of bias}

\begin{tabular}{|c|c|c|}
\hline Bias & Authors' judgement & Support for judgement \\
\hline $\begin{array}{l}\text { Random sequence genera- } \\
\text { tion (selection bias) }\end{array}$ & Unclear risk & Placebo or botulinum toxin A was randomly selected by the pharmacist \\
\hline $\begin{array}{l}\text { Allocation concealment } \\
\text { (selection bias) }\end{array}$ & Unclear risk & Vials were randomly selected by the pharmacist \\
\hline $\begin{array}{l}\text { Blinding (performance } \\
\text { bias and detection bias) } \\
\text { All outcomes }\end{array}$ & Low risk & Treator, assessor and participants blinded \\
\hline $\begin{array}{l}\text { Incomplete outcome data } \\
\text { (attrition bias) } \\
\text { All outcomes }\end{array}$ & Low risk & No missing outcome data \\
\hline $\begin{array}{l}\text { Selective reporting (re- } \\
\text { porting bias) }\end{array}$ & Unclear risk & The definition of relapse was not provided \\
\hline Other bias & Unclear risk & Did not state if syndromal CTEV type feet were excluded \\
\hline
\end{tabular}

\section{El-Deeb 2007}

\begin{tabular}{ll} 
Methods & Quasi-RCT. Two-arm parallel-group design \\
\hline Participants & 46 participants with 66 feet with resistant idiopathic CTEV, referred to a single centre
\end{tabular}


Inclusion criteria: idiopathic CTEV which failed conservative treatment (techniques unknown), requir-

ing posteromedial soft tissue release

Exclusion criteria: none stated

PARTICIPANT CHARACTERISTICS

Age mean (range) in months: 9 (3 to 24$)$

Sex male (\%): $89 \%$

Characteristics of feet: 11 left, 15 right, 20 bilateral

Baseline severity: 51 feet Dimeglio grade IV (very severe), 15 feet Dimeglio grade III (severe)

Talocalcaneal interosseous ligament released

Characteristics of feet: not stated

Talocalcaneal interosseous ligament not released

Characteristics of feet: not stated

Interventions

Talocalcaeal interosseous ligament release versus control in posteromedial soft tissue release for resistant CTEV

Randomisation of feet (not participants)

Feet were allocated equally on an alternate basis

Postoperative care was the same in both groups. Long leg plaster in corrected position which was then changed every 3 weeks into an overcorrected position. Total time immobilised in cast was 12 weeks. Antivarus boots or splints then worn for one year

Follow-up average in months: 28 (24 to 36 )

Radiological: $x$-ray
Radiological: MRI scans at 5 months postoperatively in 40 participants (20 from each group)
Scoring system based on combination of clinical and radiographic outcomes at an average of 28
months (range, 24 to 36 months)

\section{Notes}

\section{Risk of bias}

\begin{tabular}{lll}
\hline Bias & Authors' judgement & Support for judgement \\
\hline $\begin{array}{l}\text { Random sequence genera- } \\
\text { tion (selection bias) }\end{array}$ & High risk & Alternate sequence generation \\
\hline $\begin{array}{l}\text { Allocation concealment } \\
\text { (selection bias) }\end{array}$ & High risk & Alternate sequence generation \\
\hline $\begin{array}{l}\text { Blinding (performance } \\
\text { bias and detection bias) } \\
\text { All outcomes }\end{array}$ & High risk & $\begin{array}{l}\text { Unable to blind intervention provider. Unsure if assessors were blinded. Un- } \\
\text { sure if families were aware which surgery was done }\end{array}$ \\
\hline $\begin{array}{l}\text { Incomplete outcome data } \\
\text { (attrition bias) } \\
\text { All outcomes }\end{array}$ & Unclear risk & $\begin{array}{l}\text { Some participants had MRI scans. Unable to provide to all participants due to } \\
\text { logistics and cost, unsure how the limited numbers were selected }\end{array}$ \\
\hline
\end{tabular}


El-Deeb 2007 (Continued)

Selective reporting (re- Unclear risk The Simons system of reporting was modified. Mentioned cosmetic appearporting bias) ance, clinical range and strength, but did not report on these

Other bias

Unclear risk

Unsure if groups were comparable at baseline

Harnett 2011

\begin{tabular}{ll}
\hline Methods & RCT. Two-arm parallel-group design \\
\hline Participants & 40 participants with 60 feet who presented to a single centre \\
Inclusion criteria: idiopathic CTEV, less than 90 days of age, local resid & Exclusion criteria: none stated \\
& PARTICIPANT CHARACTERISTICS \\
& Age mean (range): 31 days (7 to 55) \\
& Ponseti standard group \\
& Sex male (\%): $48 \%$ \\
& Characteristics of feet: 21 participants (32 feet). 11 bilateral cases \\
& Baseline severity: median Pirani score 5 (range 4 to 6$)$ \\
& Ponseti accelerated group \\
& Sex male (\%): $53 \%$ \\
& Characteristics of feet: 19 participants (29 feet), 9 bilateral cases \\
Baseline severity: median Pirani score 5.5 (range 4.5 to 6)
\end{tabular}

Interventions

Ponseti standard protocol versus Ponseti accelerated protocol for treatment of initial CTEV

Participants were randomised (not feet)

The Ponseti standard group underwent treatment with long leg plaster casts (toe to groin) which were changed weekly. An Achilles tenotomy was performed if dorsiflexion was $<10^{\circ}$. They then wore abduction bracing for 23 hours per day for 3 months followed by night-time wear only, until 3 years of age.

The Ponseti accelerated group underwent the same treatment with the exception that long leg plaster casts were changed 3 times per week. If the deformity did not correct within 21 days the participant reverted to the standard protocol of weekly changes

Follow-up: minimum 6 months (average 251 days)

\begin{tabular}{ll}
\hline Outcomes & Pirani score \\
& Number of days to correction (prior to an Achilles tenotomy)
\end{tabular}

Notes There were no relapses at follow-up

\section{Risk of bias}

\section{Bias}

Authors' judgement Support for judgement 
Harnett 2011 (Continued)

Random sequence genera- Low risk $\quad$ Computer number generation
tion (selection bias)

\begin{tabular}{lll}
$\begin{array}{l}\text { Allocation concealment } \\
\text { (selection bias) }\end{array}$ & High risk & It was not possible for the intervention providers or participants to be blinded \\
\hline $\begin{array}{l}\text { Blinding (performance } \\
\text { bias and detection bias) } \\
\text { All outcomes }\end{array}$ & Unclear risk & Unable to blind participants. Not stated if assessor was blinded \\
\hline
\end{tabular}

Incomplete outcome data Unclear risk One child died during treatment. Intention-to-treat analysis used
(attrition bias)

All outcomes

\begin{tabular}{lll}
\hline $\begin{array}{l}\text { Selective reporting (re- } \\
\text { porting bias) }\end{array}$ & Unclear risk & Insufficient information to permit judgement \\
\hline Other bias & Unclear risk & Transport costs were covered to minimise loss to follow-up \\
\hline
\end{tabular}

Kaewpornsawan 2007

\begin{tabular}{|c|c|}
\hline Methods & RCT. Two-arm parallel-group design \\
\hline \multirow[t]{14}{*}{ Participants } & 86 participants with 128 CTEV feet \\
\hline & $\begin{array}{l}\text { Inclusion criteria: idiopathic CTEV which failed conservative treatment (treatment unknown), requiring } \\
\text { surgery }\end{array}$ \\
\hline & $\begin{array}{l}\text { Exclusion criteria: children with arthrogryposis multiplex congenita, myelomeningocoele, cerebral pal- } \\
\text { sy, syndromic clubfoot. Failed previous CTEV surgery }\end{array}$ \\
\hline & PARTICIPANT CHARACTERISTICS \\
\hline & Modified posteromedial release \\
\hline & Age mean (range) in months: 5.8 (3 to 12 ) \\
\hline & Sex male (\%): $55.3 \%$ \\
\hline & Characteristics of feet: 25 unilateral, 22 bilateral \\
\hline & $\begin{array}{l}\text { Baseline severity: Dimeglio grade 1, } 1 \text { foot; Dimeglio grade 2, } 26 \text { feet; Dimeglio grade 3, } 35 \text { feet; Dimeglio } \\
\text { grade 4, } 7 \text { feet }\end{array}$ \\
\hline & Modified complete subtalar release \\
\hline & Age mean (range) in months: 6 ( 3 to 12 ) \\
\hline & Sex male (\%): $56.4 \%$ \\
\hline & Characteristics of feet: 19 unilateral, 20 bilateral \\
\hline & $\begin{array}{l}\text { Baseline severity: Dimeglio grade 1, } 2 \text { feet; Dimeglio grade 2, } 28 \text { feet; Dimeglio grade 3, } 29 \text { feet; Dimeglio } \\
\text { grade 4, } 0 \text { feet }\end{array}$ \\
\hline
\end{tabular}


Modified posteromedial release: standard posteromedial approach. Lengthening of tendo Achilles and tibialis posterior. Release of the origin of abductor hallucis, capsulotomy of the talonavicular, posterior tibiotalar, the talocalcaneal and medial calcaneocuboid joints. Division of plantar, calcaneofibular, superficial deltoid, spring ligament and master knot of Henry. In cases with residual toe flexion, FHL and FDL were lengthened. Kirschener wires were inserted through the talonavicular and talocalcaneal joint

Modified subtalar release: a Cincinnati incision was used. The talocalcaneal and deep deltoid ligament were preserved. The talonavicular and calcaneocuboid joint were opened medially and laterally. Kirschener wires were inserted through the talonavicular and talocalcaneal joint

Both groups had the same postoperative care. Kirschner wires were removed at 6 weeks postoperatively. Long leg casts remained in situ for 12 weeks postoperatively

After cast removal, orthopaedic shoes or Denis-Brown boots were prescribed (length of time not stated)

Follow-up average: 19.4 months

\begin{tabular}{|c|c|c|}
\hline \multirow[t]{3}{*}{ Outcomes } & \multicolumn{2}{|l|}{ Ponseti score } \\
\hline & \multicolumn{2}{|l|}{ Turco evaluation } \\
\hline & \multicolumn{2}{|l|}{ Dimeglio scale } \\
\hline Notes & \multicolumn{2}{|c|}{ Basline assessment of groups $P=0.06$} \\
\hline \multicolumn{3}{|l|}{ Risk of bias } \\
\hline Bias & Authors' judgement & Support for judgement \\
\hline $\begin{array}{l}\text { Random sequence genera- } \\
\text { tion (selection bias) }\end{array}$ & Unclear risk & Simple randomisation by envelope \\
\hline $\begin{array}{l}\text { Allocation concealment } \\
\text { (selection bias) }\end{array}$ & Unclear risk & $\begin{array}{l}\text { "The surgeon blindly opened the envelope that indicated the type of surgery." } \\
\text { Unsure if sequentially numbered or opaque }\end{array}$ \\
\hline $\begin{array}{l}\text { Blinding (performance } \\
\text { bias and detection bias) } \\
\text { All outcomes }\end{array}$ & High risk & $\begin{array}{l}\text { Assessor blinding not stated. Intervention provider unable to be blinded. Par- } \\
\text { ticipant blinding unlikely to affect outcome }\end{array}$ \\
\hline $\begin{array}{l}\text { Incomplete outcome data } \\
\text { (attrition bias) } \\
\text { All outcomes }\end{array}$ & Low risk & No missing data \\
\hline $\begin{array}{l}\text { Selective reporting (re- } \\
\text { porting bias) }\end{array}$ & Unclear risk & Insufficent information to permit judgement \\
\hline Other bias & Unclear risk & Prior treatment was not outlined \\
\hline
\end{tabular}

\section{Lahoti 2008}

\begin{tabular}{ll}
\hline Methods & RCT. Matched pair design \\
\hline Participants & 13 participants with bilateral CTEV requiring soft tissue release \\
& Inclusion criteria: bilateral resistant CTEV undergoing soft tissue release \\
& Exclusion criteria: none stated
\end{tabular}


Lahoti 2008 (Continued)

\section{PARTICIPANT CHARACTERISTICS}

Age mean (range) in months: 10 (9 to 12 )

Baseline severity: 11 idiopathic cases, 2 syndromal cases. Pirani score 5.5 in 6 children and 6 in 7 children

FHL and FDL lengthening

Age mean: 10 months

Sex male (\%): $77 \%$

Characteristics of feet: 13 feet. 5 right, 8 left

Baseline severity: 5.5 average Pirani score

FHL and FDL decompression

Age mean: 10 months

Sex male (\%): $77 \%$

Characteristics of feet: 13 feet. 8 left, 5 right

Baseline severity: 5.5 average Pirani score

Lengthening of FHL and FDL versus simple decompression of the same muscles during soft tissue release for resistant CTEV

Randomisation of feet (not participants)

All participants had bilateral CTEV requiring surgery

All feet underwent a complete soft tissue release through the Cinicinnati incision. One side was randomly selected to undergo FHL and FDL lengthening, the other side simple decompression

Postoperative management the same in all feet

Follow-up average: 48 months

\begin{tabular}{ll}
\hline Outcomes & Harrold and Walker scale \\
& Pirani score
\end{tabular}

\section{Notes}

\section{Risk of bias}

\begin{tabular}{lll}
\hline Bias & Authors' judgement & Support for judgement \\
\hline $\begin{array}{l}\text { Random sequence genera- } \\
\text { tion (selection bias) }\end{array}$ & Unclear risk & Not stated \\
\hline $\begin{array}{l}\text { Allocation concealment } \\
\text { (selection bias) }\end{array}$ & Unclear risk & Insufficient information \\
\hline $\begin{array}{l}\text { Blinding (performance } \\
\text { bias and detection bias) } \\
\text { All outcomes }\end{array}$ & High risk & $\begin{array}{l}\text { Surgeon not blinded to intervention. Assessors were blinded. Blinding of par- } \\
\text { ticipants unlikely to affect outcome }\end{array}$ \\
\hline $\begin{array}{l}\text { Incomplete outcome data } \\
\text { (attrition bias) }\end{array}$ & Low risk & No missing data \\
\hline
\end{tabular}


Lahoti 2008 (Continued)

All outcomes

Selective reporting (re- Unclear risk Insufficient information on outcome measures
porting bias)

Other bias Unclear risk 2 syndromic feet were included

Manzone 1999

\begin{tabular}{ll} 
Methods & RCT. Two-arm parallel-group design \\
\hline Participants & 20 participants with 30 CTEV feet \\
& Inclusion criteria: resistant CTEV which had not undergone prior conservative treatment
\end{tabular}

Exclusion criteria: none stated

PARTICIPANT CHARACTERISTICS

Age mean (range) in months: 7.7 (3.5 to 19)

Sex male (\%): $75 \%$

Characteristics of feet: 13 right, 17 left; 20 of these were bilateral, 10 were unilateral

Basline severity: unknown.

Groups were matched for birthweight, age of treatment (between 3 months and walking age), weight at surgery, neurologic skills development at surgery, geographic origin, socioeconomic status and associated pathologies

\section{$\underline{\text { PMR }}$}

Characteristics of feet: 15 feet in total (12 participants), 6 bilateral, 5 unilateral. The remaining 4 feet ( 2 participants) were bilateral cases where one foot was randomised to each group

Baseline severity: not stated

CCSR

Characteristics of feet: 15 feet in total (12 participants), 6 bilateral, 5 unilateral. The remaining 4 feet ( 2 participants) were bilateral cases where one foot was randomised to each group

Baseline severity: not stated

PMR versus CCSR

Randomisation of feet

The PMR was completed as described by Turco with some modifications. A long leg cast is worn for 6 weeks postoperatively. Kirschner wires are then removed and a short leg plaster is worn for a further 4 weeks. Following this an AFO is worn at night

The CCSR was completed according to McKay and Simmons using a Cincinnati approach with modifications. The Achilles tendon underwent Z-lengthening, all posteromedial tendons underwent z-plasty. The posterior tibiofibular ligament and plantar fascia were only occasionally cut. The interosseous talocalcaneal ligament was never incised. A long leg plaster with the foot in equinus was in situ for 7 to 10 days postoperatively. This was then changed to a long leg cast with the foot in dorsiflexion for a further 5 weeks. The Kirschner wires were then withdrawn and a short leg cast was worn for a further 4 weeks 
Follow-up in months (range): 27 (18 to 40 )

\begin{tabular}{|c|c|c|}
\hline Outcomes & Radiographic & \\
\hline \multicolumn{3}{|l|}{ Notes } \\
\hline \multicolumn{3}{|l|}{ Risk of bias } \\
\hline Bias & Authors' judgement & Support for judgement \\
\hline $\begin{array}{l}\text { Random sequence genera- } \\
\text { tion (selection bias) }\end{array}$ & Unclear risk & Method of randomisation not described \\
\hline $\begin{array}{l}\text { Allocation concealment } \\
\text { (selection bias) }\end{array}$ & Unclear risk & Insufficient information \\
\hline $\begin{array}{l}\text { Blinding (performance } \\
\text { bias and detection bias) } \\
\text { All outcomes }\end{array}$ & High risk & $\begin{array}{l}\text { Intervention provider unable to be blinded. Participant blinding unlikely to af- } \\
\text { fect outcome. Insufficient information regarding assessor blinding }\end{array}$ \\
\hline $\begin{array}{l}\text { Incomplete outcome data } \\
\text { (attrition bias) } \\
\text { All outcomes }\end{array}$ & Low risk & No missing data \\
\hline $\begin{array}{l}\text { Selective reporting (re- } \\
\text { porting bias) }\end{array}$ & Unclear risk & $\begin{array}{l}\text { Unsure of time of postoperative } x \text {-ray, unsure which groups had adverse out- } \\
\text { comes }\end{array}$ \\
\hline Other bias & Unclear risk & Unsure of baseline severity \\
\hline
\end{tabular}

\section{Pittner 2008}

\begin{tabular}{ll}
\hline Methods & RCT. Two-arm parallel-group design \\
\hline Participants & 34 participants with 42 CTEV feet who attended authors outpatient clinics \\
Inclusion criteria: initial presentation of CTEV \\
Exclusion criteria: none stated \\
PARTICIPANT CHARACTERISTICS \\
3 participants excluded prior to data analysis. 1 lost to follow-up, 1 had medical complications and 1 \\
switched groups during treatment \\
Fibreglass \\
Age mean (SD) weeks: 1.07 (0.57) \\
Sex male (\%): $69 \%$ \\
Characteristics of feet: 13 participants. 16 feet: 8 left, 8 right \\
Baseline severity: Dimeglio scale score average: 13.1 \\
Plaster
\end{tabular}


Pittner 2008 (Continued)

Age mean (SD) weeks: 1.89 (1.88)

Sex male (\%): $100 \%$

Characteristics of feet: 18 participants. 23 feet: 9 left, 14 right

Baseline severity: Dimeglio scale average: 12.3

Interventions

Semi-rigid (fibreglass) casts versus plaster of Paris casts for Ponseti treatment of initial presentation of CTEV

Randomisation was done according to medical record number. Feet were enrolled separately, but participants were randomised, i.e. if a participant had bilateral CTEV, both feet were randomised to the same group

In the semi-rigid (fibreglass) group, casting was done using Scotchcast Softcast (3M). In the control group, plaster of Paris was used

Follow-up: end of treatment

\begin{tabular}{ll}
\hline Outcomes & Dimeglio scale \\
& Parent satisfaction questionnaire \\
\hline
\end{tabular}

Notes

\section{Risk of bias}

\begin{tabular}{lll}
\hline Bias & Authors' judgement & Support for judgement \\
\hline $\begin{array}{l}\text { Random sequence genera- } \\
\text { tion (selection bias) }\end{array}$ & Unclear risk & Sequence generated by medical record number. Not stated how this was done \\
\hline $\begin{array}{l}\text { Allocation concealment } \\
\text { (selection bias) }\end{array}$ & High risk & Sequence generated by medical record number \\
\hline $\begin{array}{l}\text { Blinding (performance } \\
\text { bias and detection bias) } \\
\text { All outcomes }\end{array}$ & High risk & $\begin{array}{l}\text { Unable to blind intervention providers. Assessors not blinded. Participant } \\
\text { blinding unlikely to affect outcome }\end{array}$ \\
\hline $\begin{array}{l}\text { Incomplete outcome data } \\
\text { (attrition bias) } \\
\text { All outcomes }\end{array}$ & High risk & $\begin{array}{l}\text { Several participants were excluded after randomisation or lost to follow-up. } \\
\text { Their data were removed from the study }\end{array}$ \\
\hline $\begin{array}{l}\text { Selective reporting (re- } \\
\text { porting bias) }\end{array}$ & Unclear risk & Outcomes not stated at outset but reported in results \\
\hline \begin{tabular}{l} 
Other bias \\
\hline
\end{tabular} & Unclear risk & Insufficient information \\
\hline
\end{tabular}

Rijal 2010

\begin{tabular}{ll}
\hline Methods & RCT. Two-arm parallel-group design \\
\hline Participants & 38 participants with 60 CTEV feet who presented to one outpatient clinic \\
& Inclusion criteria: CTEV \\
& Exclusion criteria: prior intervention for CTEV, over 2 years old
\end{tabular}


Rijal 2010 (Continued)

\section{PARTICIPANT CHARACTERISTICS}

Age mean (SD, range) days: 195.7 (202.81 3 to 720 days)

Sex male (\%): $76.2 \%$

Basline severity: unclear (report states the groups were equal at baseline for age, sex and Pirani scores)

Ponseti

Characteristics of feet: 30 feet. 10 unilateral, 8 ( 4 participants) bilateral. The remaining 12 feet (12 participants) were bilateral cases where one foot was randomised to each group

Kite

Characteristics of feet: 30 feet. 6 feet unilateral, 12 feet ( 6 participants) bilateral. The remaining 12 feet (12 participants) were bilateral cases where one foot was randomised to each group

Randomisation of feet (not participants)

Casts were changed in both groups at weekly intervals for 10 weeks. Tendo Achilles tenotomy was undertaken in both groups for those with residual equinus deformity. Feet which were not corrected at the end of 10 weeks were subject to surgical correction

Follow-up: end of treatment

Outcomes Pirani score

\section{Notes}

\section{Risk of bias}

\begin{tabular}{lll}
\hline Bias & Authors' judgement & Support for judgement \\
\hline $\begin{array}{l}\text { Random sequence genera- } \\
\text { tion (selection bias) }\end{array}$ & Low risk & Computer random generation \\
\hline $\begin{array}{l}\text { Allocation concealment } \\
\text { (selection bias) }\end{array}$ & Unclear risk & Insufficient information \\
\hline $\begin{array}{l}\text { Blinding (performance } \\
\text { bias and detection bias) } \\
\text { All outcomes }\end{array}$ & High risk & $\begin{array}{l}\text { Unable to blind intervention providers. Observers were blinded. Participant } \\
\text { blinding unlikely to affect outcome }\end{array}$ \\
\hline $\begin{array}{l}\text { Incomplete outcome data } \\
\text { (attrition bias) }\end{array}$ & Low risk & No missing data \\
All outcomes & & \\
\hline $\begin{array}{l}\text { Selective reporting (re- } \\
\text { porting bias) }\end{array}$ & High risk & Insufficient information on adverse events \\
\hline \begin{tabular}{l} 
Other bias \\
\hline
\end{tabular} & Unclear risk & Unsure of operative intervention required after each intervention \\
\hline
\end{tabular}

Sanghvi 2009

Methods RCT. Two-arm parallel-group design


Sanghvi 2009 (Continued)

Participants
42 participants with 64 CTEV feet

Inclusion criteria: idiopathic CTEV, initial presentation

Exclusion criteria: myelocele, meningomyelocoele, arthrogryposis multiplex congenital, other neuromuscular disorders

\section{PARTICIPANT CHARACTERISTICS}

Basline severity: not stated

Ponseti

21 participants

Age mean (SD): 13.2 (11.9) weeks

Sex male (\%): $62 \%$

Characteristics of feet: 30 feet. 18 bilateral (9 participants): 6 right, 6 left

Baseline severity: not stated

Kite

21 participants

Age mean (SD): 12.2 (10) weeks

Sex male (\%): $67 \%$

Characteristics of feet: 34 feet. 26 bilateral (13 participants): 5 right, 3 left

Baseline severity: not stated

Interventions

Ponseti versus Kite technique for treatment of initial CTEV

Randomisation of participants to each group (not feet)

In the Ponseti group, casts were changed every 7 to 10 days. Achilles tenotomy was performed in those with residual equinus. Bracing in abduction orthosis using Denis-Brown splints was done with the affected foot at $70^{\circ}$ of external rotation and the unaffected foot at $40^{\circ}$ to $45^{\circ}$ of external rotation. Splints were worn full time until walking age, and then at night only. During the day, shoes with an open toe box, straight medial border. Lateral flaring of the sole and reverse Thomas heels were used until the age of 4 to 5 years

In the Kite group, toe to groin casts were changed every 7 to 10 days until full correction. The final position was maintained in full time bracing in a neutral position with a heel lock and straight medial bar. Once the participant began walking, the brace was used at night only. During the day, shoes with an open toe box, straight medial border, lateral flaring of the sole and reverse Thomas heels were used until the age of 4 to 5 years

Follow-up average: 36 months

Radiographic

Range of movement

Notes

\section{Risk of bias}


Sanghvi 2009 (Continued)
Random sequence genera-
Unclear risk
Insufficient information tion (selection bias)

\begin{tabular}{lll}
\hline $\begin{array}{l}\text { Allocation concealment } \\
\text { (selection bias) }\end{array}$ & Unclear risk & Insufficient information \\
\hline
\end{tabular}

\begin{tabular}{lll}
\hline $\begin{array}{l}\text { Blinding (performance } \\
\text { bias and detection bias) } \\
\text { All outcomes }\end{array}$ & High risk & $\begin{array}{l}\text { Unable to blind intervention provider. Assessor not blinded. Blinding of partici- } \\
\text { pant unlikely to affect outcome }\end{array}$ \\
\hline $\begin{array}{l}\text { Incomplete outcome data } \\
\begin{array}{l}\text { (attrition bias) } \\
\text { All outcomes }\end{array}\end{array}$ & Low risk & No missing data \\
\hline $\begin{array}{l}\text { Selective reporting (re- } \\
\text { porting bias) }\end{array}$ & High risk & $\begin{array}{l}\text { Incomplete outcome reporting, e.g. radiographic. Cannot be entered into the } \\
\text { meta-analysis }\end{array}$ \\
\hline Other bias & Unclear risk & Insufficient information on baseline assessment for both groups \\
\hline
\end{tabular}

Selmani 2012

\begin{tabular}{|c|c|}
\hline Methods & RCT. Two-arm parallel-group design \\
\hline \multirow[t]{16}{*}{ Participants } & 100 participants with 150 CTEV feet \\
\hline & Inclusion criteria: idiopathic CTEV, less than 3 months of age, initial presentation (no prior treatment) \\
\hline & $\begin{array}{l}\text { Exclusion criteria: myelocele, meningomyelocele, arthrogryposis multiplex congenital, other neuro- } \\
\text { muscular causes }\end{array}$ \\
\hline & PARTICIPANT CHARACTERISTICS \\
\hline & Ponseti \\
\hline & 50 participants \\
\hline & Age mean (SD): 35.3 (25.4) days \\
\hline & Sex male (\%): $60 \%$ \\
\hline & Characteristics of feet: 76 feet. \\
\hline & Baseline severity: Pirani Score mean (SD): $5.2(0.8)$ \\
\hline & Kite \\
\hline & 50 participants \\
\hline & Age mean (SD): 32.45 (26.3) days \\
\hline & Sex male (\%): 56\% \\
\hline & Characteristics of feet: 74 feet. \\
\hline & Baseline severity: Pirani Score mean (SD): 5.1 (0.7) \\
\hline
\end{tabular}

Randomisation of participants to each group (not feet) 
Selmani 2012 (Continued)

In the Ponseti group, casts were changed every 7 to 10 days until the foot was corrected or the participant was one year of age. Achilles tenotomy was performed in those with residual equinus. Bracing in abduction orthosis using Denis-Brown splints was done with the affected foot at $70^{\circ}$ of external rotation and the unaffected foot at $40^{\circ}$ to $45^{\circ}$ of external rotation. Splints were worn full time until walking age, and then at night only. During the day, shoes with an open toe box, straight medial border. Lateral flaring of the sole and reverse Thomas heels were used until the age of 4 years

Follow-up average (SD): 36.2 (3.2) months

In the Kite group, toe to groin casts were changed every 7 to 10 days until full correction or the participant was one year of age. The final position was maintained in full time bracing in a neutral position with a heel lock and straight medial bar. Once the participant began walking, the brace was used at night only. During the day, shoes with an open toe box, straight medial border, lateral flaring of the sole and reverse Thomas heels were used until the age of 4 years

Follow-up average (SD): 35.1 (2.5) months

Outcomes Pirani score, range of movement

Notes

\section{Risk of bias}

\begin{tabular}{lll}
\hline Bias & Authors' judgement & Support for judgement \\
\hline $\begin{array}{l}\text { Random sequence genera- } \\
\text { tion (selection bias) }\end{array}$ & Low risk & Random computer number generation \\
\hline $\begin{array}{l}\text { Allocation concealment } \\
\text { (selection bias) }\end{array}$ & Unclear risk & Insufficient information \\
\hline $\begin{array}{l}\text { Blinding (performance } \\
\text { bias and detection bias) } \\
\text { All outcomes }\end{array}$ & High risk & $\begin{array}{l}\text { Intervention provider could not be blinded. Assessors were blinded. Partici- } \\
\text { pant and carer blinding not possible, which could affect outcome }\end{array}$ \\
\hline $\begin{array}{l}\text { Incomplete outcome data } \\
\text { (attrition bias) }\end{array}$ & High risk & $\begin{array}{l}\text { Several participants were excluded after randomisation or lost to follow-up. } \\
\text { Their data were excluded from final analysis }\end{array}$ \\
\hline $\begin{array}{l}\text { Selective reporting (re- } \\
\text { porting bias) }\end{array}$ & Unclear risk & $\begin{array}{l}\text { Described functional outcome of corrected feet only. Adverse events not docu- } \\
\text { mented }\end{array}$ \\
\hline $\begin{array}{l}\text { Other bias } \\
\text { Unclear risk }\end{array}$ & $\begin{array}{l}\text { Unknown if relapsed patients were part of original failure group. Treatment for } \\
\text { relapsed cases in the Kite group not stated }\end{array}$ \\
\hline
\end{tabular}

Siddiqui 2007

\begin{tabular}{ll}
\hline Methods & RCT. Two-arm parallel-group design \\
\hline Participants & 60 patients who presented to a single centre (number of CTEV feet unknown) \\
& Inclusion criteria: CTEV with Dimeglio grade I and II undergoing surgical correction \\
& Exclusion criteria: CTEV with Dimeglio grade III and IV \\
& PARTICIPANT CHARACTERISTICS \\
& Age range in months: 6 to 18
\end{tabular}


Siddiqui 2007 (Continued)

Sex male (\%): $61.7 \%$

Basline severity: Dimeglio grade I, 20 participants; Dimeglio grade II, 40 participants

Window procedure

Age mean: 9.5 months

Characteristics of feet: 30 participants (bilateral and unilateral numbers not reported)

Baseline severity: not stated

Turco procedure

Age mean: 9.6 months

Characteristics of feet: 30 participants (bilateral and unilateral numbers not reported)

Baseline severity: not stated

Interventions

Window procedure versus Turco procedure for treatment of CTEV

Participants were randomised equally into both groups

The Window procedure was not described in detail in the article. It utilises five or six small incisions rather than a long posteromedial incision. Postoperatively the foot is placed in a plaster in the corrected position. Details of the plaster were not provided

In the Turco group, postoperatively a cast was not applied for 15 days because of oedema

Follow-up: not stated

Dimeglio scale
Postoperative assessment criteria according to Beatson 6 months after surgery
Time in theatre
Adverse events

Notes

\section{Risk of bias}

\begin{tabular}{|c|c|c|}
\hline Bias & Authors' judgement & Support for judgement \\
\hline $\begin{array}{l}\text { Random sequence genera- } \\
\text { tion (selection bias) }\end{array}$ & Unclear risk & Insufficient information \\
\hline $\begin{array}{l}\text { Allocation concealment } \\
\text { (selection bias) }\end{array}$ & Unclear risk & Insufficient information \\
\hline $\begin{array}{l}\text { Blinding (performance } \\
\text { bias and detection bias) } \\
\text { All outcomes }\end{array}$ & High risk & $\begin{array}{l}\text { Unable to blind intervention provider. Assessor blinding not reported. Partici- } \\
\text { pant blinding unlikely to affect outcome }\end{array}$ \\
\hline $\begin{array}{l}\text { Incomplete outcome data } \\
\text { (attrition bias) } \\
\text { All outcomes }\end{array}$ & Low risk & No missing data \\
\hline $\begin{array}{l}\text { Selective reporting (re- } \\
\text { porting bias) }\end{array}$ & Unclear risk & Follow-up time not reported \\
\hline
\end{tabular}


Siddiqui 2007 (Continued)

$\begin{array}{ll}\text { Other bias } \quad \text { High risk } & \text { Procedure was developed, used and assessed by the same team within the } \\ \text { same population. Bilateral and unilateral numbers not reported. Follow-up }\end{array}$ times not reported

Sud 2008

\begin{tabular}{|c|c|}
\hline Methods & Quasi RCT. Two-arm parallel-group design \\
\hline \multirow[t]{15}{*}{ Participants } & 53 participants with 81 CTEV feet who presented to a single centre \\
\hline & Inclusion criteria: $<3$ months of age, idiopathic CTEV \\
\hline & Exclusion criteria: non-idiopathic CTEV, $>3$ months of age \\
\hline & PARTICIPANT CHARACTERISTICS \\
\hline & 8 participants lost to follow-up and excluded prior to data analysis \\
\hline & Ponseti \\
\hline & Age mean (SD) days: 31.75 (27.4) \\
\hline & Sex male (\%): $60.8 \%$ \\
\hline & Characteristics of feet: 23 participants, 36 feet. 26 bilateral (13 participants), 4 right, 6 left \\
\hline & Baseline severity (Dimeglio scale score mean (SD)): 14.39 (3.2) \\
\hline & Kite \\
\hline & Age mean (SD) days: $26.06(21.4)$ \\
\hline & Sex male (\%): $77.2 \%$ \\
\hline & Characteristics of feet: 22 participants, 31 feet. 18 bilateral (9 participants), 5 right, 8 left \\
\hline & Baseline severity (Dimeglio scale score mean (SD)): 16.19 (2.8) \\
\hline
\end{tabular}

Interventions

Ponseti versus Kite

Randomisation of participants (not feet)

In the Ponseti group, weekly manipulation and casting was done until correction or 1 year (whichever came first). Correction was defined as $50^{\circ}$ to $60^{\circ}$ external rotation and $15^{\circ}$ dorsiflexion with or without an Achilles tenotomy. Following correction, feet were placed in abduction bracing at $50^{\circ}$ to $60^{\circ}$ of external rotation, worn full time for 2 to 3 months then at night until 2 to 4 years of age

In the Kite group, manipulation and casting was done till the foot was corrected. Correction was maintained in a night brace in dorsiflexion and slight valgus

Follow-up average: 26 months

\begin{tabular}{ll}
\hline Outcomes & Dimeglio scale \\
& Range of movement
\end{tabular}

\section{Notes}

\section{Risk of bias}


Sud 2008 (Continued)

Bias Authors' judgement Support for judgement

Random sequence genera- High risk Alternate allocation

tion (selection bias)

\begin{tabular}{lll}
\hline $\begin{array}{l}\text { Allocation concealment } \\
\text { (selection bias) }\end{array}$ & High risk & Alternate allocation
\end{tabular}

\begin{tabular}{|c|c|c|}
\hline $\begin{array}{l}\text { Blinding (performance } \\
\text { bias and detection bias) } \\
\text { All outcomes }\end{array}$ & High risk & $\begin{array}{l}\text { Intervention provider unable to be blinded. Assessor was blinded. Participant } \\
\text { blinding unlikely to affect outcome }\end{array}$ \\
\hline
\end{tabular}

\begin{tabular}{lll}
\hline $\begin{array}{l}\text { Incomplete outcome data } \\
\text { (attrition bias) } \\
\text { All outcomes }\end{array}$ & High risk & 8 participants were excluded or lost to follow-up and excluded from analysis \\
\hline $\begin{array}{l}\text { Selective reporting (re- } \\
\text { porting bias) }\end{array}$ & High risk & Prespecified outcomes were unclear in methods \\
\hline Other bias & Unclear risk & Insufficient information to permit judgment \\
\hline
\end{tabular}

Zeifang 2005

\begin{tabular}{|c|c|}
\hline Methods & RCT, two-arm parallel group design \\
\hline \multirow[t]{12}{*}{ Participants } & 36 participants with 36 CTEV feet who presented to a single centre \\
\hline & $\begin{array}{l}\text { Inclusion criteria: idiopathic CTEV. Failed conservative treatment for } 6 \text { months. Dimeglio grade III. Un- } \\
\text { derwent posteromedial lateral release }\end{array}$ \\
\hline & Exclusion criteria: none stated \\
\hline & PARTICIPANT CHARACTERISTICS \\
\hline & In bilateral cases, one foot was randomly selected by tossing a coin \\
\hline & $\begin{array}{l}1 \text { bilateral case with early relapse was excluded prior to data analysis (leaving } 37 \text { participants with } 37 \\
\text { feet for analysis) }\end{array}$ \\
\hline & Age mean (range) in months: 8.2 (5 to 12 ) \\
\hline & Sex male (\%): $71 \%$ \\
\hline & $\underline{\mathrm{CPM}}$ \\
\hline & Characteristics of feet: 18 feet \\
\hline & Immobilisation in a cast \\
\hline & Characteristics of feet: 19 feet \\
\hline
\end{tabular}

Interventions

CPM versus immobilisation in a cast, after surgery for resistant CTEV

Randomisation of participants. However, bilateral feet received the same postoperative management.

In both groups a cast was applied postoperatively for the first 10 days. Kirschner wires were removed from all feet 2 weeks postoperatively

In the casting group, casting for another 4.5 weeks was undertaken 
Zeifang 2005 (Continued)

In the CPM group, computer-assisted 3-dimensional therapy using a Kinetic 5090 Ankle CPM machine was used with a standardised protocol. CPM was applied for 4 hours per day. During rest periods, removable splints were applied

6 weeks after surgery, all feet were treated with a brace at night. Physiotherapy was provided to both groups for a further 6 months. When the participants began to walk, they were provided with heel cups to place in conventional shoes

Follow-up: 48 months

\begin{tabular}{ll}
\hline Outcomes $\quad$ Dimeglio scale \\
\hline Notes
\end{tabular}

\section{Risk of bias}

\begin{tabular}{lll}
\hline Bias & Authors' judgement & Support for judgement \\
\hline $\begin{array}{l}\text { Random sequence genera- } \\
\text { tion (selection bias) }\end{array}$ & Low risk & Computer number generation \\
\hline $\begin{array}{l}\text { Allocation concealment } \\
\text { (selection bias) }\end{array}$ & Unclear risk & Insufficient information \\
\hline $\begin{array}{l}\text { Blinding (performance } \\
\text { bias and detection bias) } \\
\text { All outcomes }\end{array}$ & High risk & $\begin{array}{l}\text { Intervention provider could not be blinded. Assessors were blinded. Partici- } \\
\text { pant and carer blinding not possible, which could affect outcome }\end{array}$ \\
\hline $\begin{array}{l}\text { Incomplete outcome data } \\
\text { (attrition bias) } \\
\text { All outcomes }\end{array}$ & High risk & $\begin{array}{l}\text { Two feet were lost to follow-up. One participant was excluded after randomi- } \\
\text { sation and removed from data analysis }\end{array}$ \\
\hline $\begin{array}{l}\text { Selective reporting (re- } \\
\text { porting bias) }\end{array}$ & High risk & Compliance with CPM unclear. No measurement of pain postoperatively \\
\hline \begin{tabular}{l} 
Other bias \\
\hline
\end{tabular} & Unclear risk & Insufficient information to permit judgement \\
\hline
\end{tabular}

Zwick 2009

\begin{tabular}{ll}
\hline Methods & RCT. Two-arm parallel-group design \\
\hline Participants & 19 participants with 28 CTEV feet who presented to a single centre \\
& Inclusion criteria: idiopathic CTEV, less than 2 weeks of age \\
& Exclusion criteria: none stated \\
& PARTICIPANT CHARACTERISTICS \\
& Ponseti \\
& Age mean (SD) weeks: 0.7 (0.8) \\
& Sex male (\%): $33 \%$ \\
& Characteristics of feet: 9 participants (12 feet) \\
& 2 participants ( 2 feet) opted out. Intention-to treat-analysis was done.
\end{tabular}


Zwick 2009 (Continued)

Baseline severity: Pirani score 4.6 (1.5)

Posteromedial soft tissue release

Age mean (SD) weeks: $0.4(0.4)$

Sex male (\%): $70 \%$

Characteristics of feet: 10 participants (16 feet)

Baseline severity: Pirani score 4.5 (1.1)

Interventions

Ponseti versus surgical intervention

Randomisation was done on participants

Treatment using the Ponseti technique was done with long leg casts changed weekly. All participants required an Achilles tenotomy which were done under general anaesthesia and then placed back into a long leg cast for a further 3 weeks. Correction was maintained in a brace with external rotation of $70^{\circ}$ for affected feet and $45^{\circ}$ for unaffected feet. The brace was worn full time until 6 months of age, then for 18 hours per day until the child started standing. Once standing, the brace was worn at night until 2 years of age. Following this participants were placed into custom moulded shoes with an insole with a heel counter, moderate flange at the medial aspect of the cuboid and medial aspect of the first metatarsal head

Participants in the surgical group underwent similar weekly manipulative casting as those in the Ponseti group until 6 to 8 months of age. All residual deformities were then treated with a posteromedial release via a Cincinnati incision and fixated with Kirschner wires and long leg casts. Kirschner wires were removed at 4 weeks and casts removed at 6 weeks postoperatively. Correction was maintained with rigid knee ankle foot orthoses, worn at night until 3 years of age. Moulded orthoses were prescribed once the participant was able to stand and walk

Follow-up average: 42 months

\begin{tabular}{lll}
\hline Outcomes & Pirani score & \\
& PODCI & \\
& Functional Rating System (FRS) Laaveg and Ponseti \\
\hline Notes & & \\
\hline Risk of bias & Authors' judgement & Support for judgement \\
\hline Bias & Low risk & Random number table \\
\hline $\begin{array}{l}\text { Random sequence genera- } \\
\text { tion (selection bias) }\end{array}$ & Unclear risk & \begin{tabular}{l} 
Insufficient information \\
\hline $\begin{array}{l}\text { Allocation concealment } \\
\text { (selection bias) }\end{array}$
\end{tabular} \\
\hline $\begin{array}{l}\text { Blinding (performance } \\
\text { bias and detection bias) } \\
\text { All outcomes }\end{array}$ & High risk & $\begin{array}{l}\text { Blinding of intervention provider not possible. Assessor not blinded. Unable to } \\
\text { blind participants or families }\end{array}$ \\
\hline $\begin{array}{l}\text { Incomplete outcome data } \\
\text { (attrition bias) } \\
\begin{array}{l}\text { All outcomes } \\
\hline\end{array}\end{array}$ & High risk & $\begin{array}{l}\text { 'As-treated' analysis done with substantial departure of the intervention re- } \\
\text { ceived from that assigned at randomisation }\end{array}$ \\
\hline
\end{tabular}


Zwick 2009 (Continued)

Selective reporting (re- Unclear risk Insufficient information
porting bias)

Other bias High risk

Stopped early secondary to ethical implications. The traditional technique was leading to greater rates of major surgical intervention compared to the Ponseti technique. Different assessors for different outcome measures

AFO: ankle foot orthosis

CPM: continuous passive motion

CTEV: congenital talipes equinovarus

FDL: flexor digitorum longus

FHL: flexor hallucis longus

MRI: magnetic resonance imaging

PODCl: Pediatric Outcomes Data Collection Instrument

$\mathrm{RCT}$ : randomised controlled trial

SD: standard deviation

Characteristics of excluded studies [ordered by study ID]

\begin{tabular}{|c|c|}
\hline Study & Reason for exclusion \\
\hline Andriesse 2008 & Not an RCT. Allocation was consecutive \\
\hline Atar 1993 & Not an RCT \\
\hline Aurell 2005 & $\begin{array}{l}\text { Not an RCT. Treatment was allocated according to which hospital the participant at- } \\
\text { tended }\end{array}$ \\
\hline Chang 1991 & Not an RCT \\
\hline DePuy 1989 & Not an RCT. A retrospective review of treatment method \\
\hline DeRosa 1986 & Not an RCT \\
\hline Dimeglio 1996 & Not an RCT \\
\hline Doğan 2002 & Not an RCT \\
\hline Farsetti 2009 & Not an RCT \\
\hline Faulks 2009 & Not an RCT. A controlled clinical trial \\
\hline Halanski 2010 & Not an RCT. A controlled clinical trial \\
\hline Ippolito 2003 & Not an RCT \\
\hline Janicki 2011 & Not an RCT \\
\hline Kesemenli 2003 & Not an RCT \\
\hline Kuo 2001 & Not an RCT \\
\hline Li 2007 & Not an RCT \\
\hline Miura 2005 & No mention of randomisation \\
\hline
\end{tabular}




\begin{tabular}{|c|c|}
\hline Study & Reason for exclusion \\
\hline Napiontek 2000 & Not an RCT \\
\hline Narang 2011 & Not an RCT \\
\hline Nilgün 2011 & Not an RCT \\
\hline O'Brien 2004 & Not an RCT. A retrospective review \\
\hline Ponseti 2006 & Not an RCT. A case series \\
\hline Richards 2008 & Not an RCT. A controlled clinical trial \\
\hline Simons 1985 & Not an RCT \\
\hline Steinman 2009 & Not an RCT. A controlled clinical trial \\
\hline Thompson 1982 & No mention of randomisation \\
\hline Tschopp 2002 & Not an RCT \\
\hline Uglow 2000 & Not an RCT \\
\hline Xu 2011 & Not an RCT \\
\hline
\end{tabular}

$\mathrm{RCT}$ : randomised controlled trial

Characteristics of ongoing studies [ordered by study ID]

\begin{tabular}{ll}
\hline NCT01067651 & Comparison of casting materials for the treatment of clubfoot using the Ponseti method \\
\hline Methods & Randomised, parallel assignment, open label \\
\hline Participants & Infants up to 12 weeks of age with congenital idiopathic clubfoot \\
\hline Interventions & $\begin{array}{l}\text { Plaster of Paris (POP) or semi-rigid fibreglass softcast (SRF, 3M Scotchcast), using the Ponseti } \\
\text { method }\end{array}$ \\
\hline Outcomes & $\begin{array}{l}\text { Primary: number of casts required for correction } \\
\text { Secondary: need for tenotomy, ease of cast removal, time of cast removal, methods of cast re- } \\
\text { moval, other concerns about the casting material }\end{array}$ \\
\hline Starting date & Not given \\
\hline Contact information & Jason Howard, MD \\
\hline Notes & Alberta Children's Hospital, Calgary, Canada \\
\hline
\end{tabular}


DATA AND ANALYSES

Comparison 1. Kite versus Ponseti technique for treatment of initial CTEV

\begin{tabular}{llllll}
\hline Outcome or subgroup title & $\begin{array}{l}\text { No. of } \\
\text { studies }\end{array}$ & $\begin{array}{l}\text { No. of } \\
\text { partici- } \\
\text { pants }\end{array}$ & Statistical method & Effect size \\
\hline 1 Pirani score at 10 weeks & 1 & 60 & Mean Difference (Fixed, 95\% Cl) & $-1.15[-1.32,-0.98]$ \\
\hline $\begin{array}{l}1.1 \text { Bilateral cases, one foot assigned to Pon- } \\
\text { seti, one to Kite }\end{array}$ & 1 & 24 & Mean Difference (Fixed, 95\% Cl) & $-1.16[-1.35,-0.97]$ \\
\hline $\begin{array}{l}1.2 \text { Bilateral cases, both feet assigned to the } \\
\text { same treatment (Ponseti or Kite) }\end{array}$ & 1 & 20 & Mean Difference (Fixed, 95\% Cl) & $-1.24[-1.81,-0.67]$ \\
\hline $\begin{array}{l}1.3 \text { Unilateral cases, assigned to either Pon- } \\
\text { seti or Kite }\end{array}$ & 1 & 16 & Mean Difference (Fixed, 95\% Cl) & $-0.86[-1.52,-0.20]$ \\
\hline
\end{tabular}

Analysis 1.1. Comparison 1 Kite versus Ponseti technique for treatment of initial CTEV, Outcome 1 Pirani score at 10 weeks.

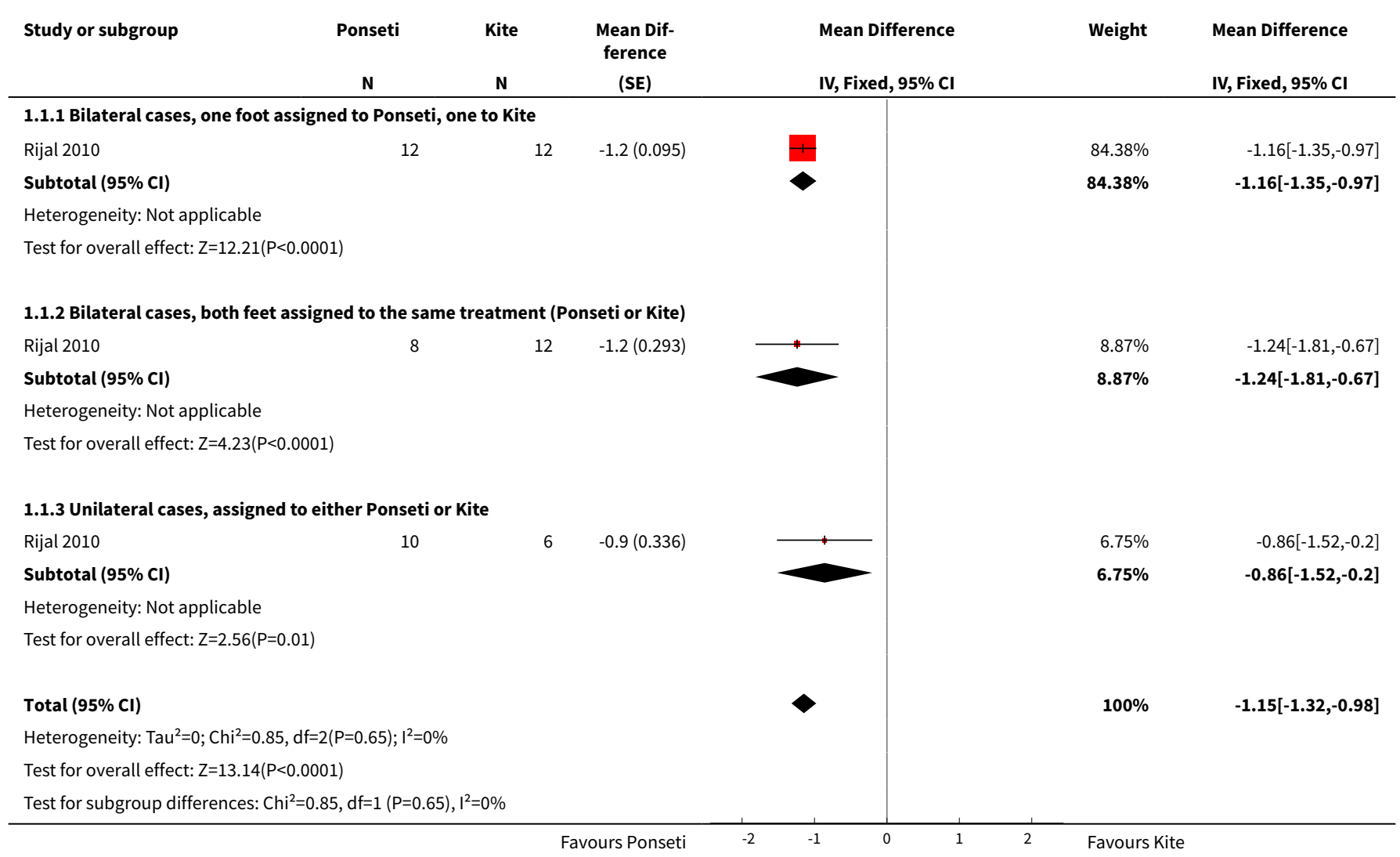


Comparison 2. Ponseti versus traditional treatment (plaster casting and surgery) for treatment of initial CTEV

\begin{tabular}{llllll}
\hline Outcome or subgroup title & $\begin{array}{l}\text { No. of } \\
\text { studies }\end{array}$ & $\begin{array}{l}\text { No. of par- } \\
\text { ticipants }\end{array}$ & Statistical method & Effect size \\
\hline 1 Pirani score at end of serial plaster casting & 1 & 28 & Mean Difference (Fixed, 95\% Cl) & $-1.5[-2.28,-0.72]$ \\
\hline
\end{tabular}

Analysis 2.1. Comparison 2 Ponseti versus traditional treatment (plaster casting and surgery) for treatment of initial CTEV, Outcome 1 Pirani score at end of serial plaster casting.

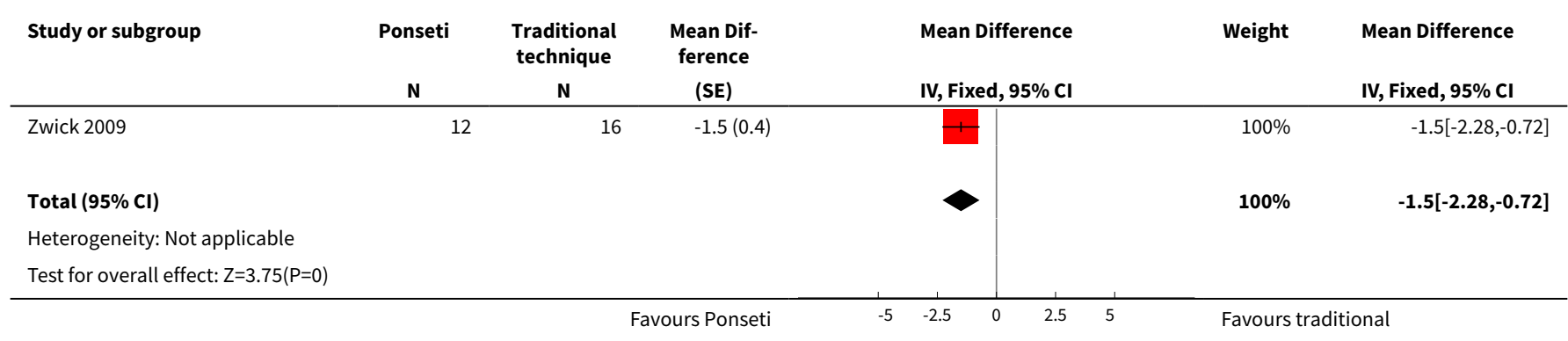

\section{Comparison 3. Standard Ponseti technique versus an accelerated Ponseti technique}

\begin{tabular}{llllll}
\hline Outcome or subgroup title & $\begin{array}{l}\text { No. of } \\
\text { studies }\end{array}$ & $\begin{array}{l}\text { No. of par- } \\
\text { ticipants }\end{array}$ & Statistical method & Effect size \\
\hline 1 Pirani score at the end of serial plaster casting & 1 & 40 & Mean Difference (Fixed, 95\% Cl) & $0.31[-0.40,1.02]$ \\
\hline
\end{tabular}

Analysis 3.1. Comparison 3 Standard Ponseti technique versus an accelerated Ponseti technique, Outcome 1 Pirani score at the end of serial plaster casting.

\begin{tabular}{|c|c|c|c|c|c|c|}
\hline Study or subgroup & $\begin{array}{c}\text { Accelerated } \\
\text { Ponseti } \\
\mathbf{N} \\
\end{array}$ & $\begin{array}{c}\text { Standard } \\
\text { Ponseti } \\
\mathbf{N} \\
\end{array}$ & $\begin{array}{l}\text { Mean Dif- } \\
\text { ference } \\
\text { (SE) }\end{array}$ & $\begin{array}{l}\text { Mean Difference } \\
\text { IV, Fixed, } 95 \% \mathrm{CI}\end{array}$ & Weight & $\begin{array}{l}\text { Mean Difference } \\
\text { IV, Fixed, } 95 \% \mathrm{CI}\end{array}$ \\
\hline Harnett 2011 & 19 & 21 & $0.3(0.363)$ & & $100 \%$ & $0.31[-0.4,1.02]$ \\
\hline Total $(95 \% \mathrm{CI})$ & & & & & $100 \%$ & $0.31[-0.4,1.02]$ \\
\hline \multicolumn{7}{|c|}{ Heterogeneity: Not applicable } \\
\hline
\end{tabular}

\section{ADDITIONAL TABLES}




\begin{tabular}{|c|c|c|c|c|c|c|c|c|}
\hline Study ID & $\begin{array}{l}\text { No.No.Method of } \\
\text { of of randomisa- } \\
\quad \text { tion (feet / } \\
\text { parfeetpartici- } \\
\text { tic- pants) } \\
\text { i- } \\
\text { pants }\end{array}$ & $\begin{array}{l}\text { Combin- } \\
\text { ing of all } \\
\text { feet in bi- } \\
\text { lateral } \\
\text { and uni- } \\
\text { lateral } \\
\text { cases? }\end{array}$ & $\begin{array}{l}\text { CTEV } \\
\text { case }\end{array}$ & $\begin{array}{l}\text { CTEV } \\
\text { diagnosis }\end{array}$ & $\begin{array}{l}\text { Average } \\
\text { start } \\
\text { age (SD) }\end{array}$ & Treatment & $\begin{array}{l}\text { Outcome } \\
\text { measure }\end{array}$ & $\begin{array}{l}\text { Av- } \\
\text { er- } \\
\text { age } \\
\text { Fol- } \\
\text { low-up } \\
\text { time } \\
\text { (months }\end{array}$ \\
\hline $\begin{array}{l}\text { Cummings } \\
2009\end{array}$ & 2032 Participants & $\mathrm{Y}$ & Initial & Not stated & $\begin{array}{l}0 \text { to } 30 \\
\text { days }\end{array}$ & Botulinum toxin versus placebo with Ponseti technique & $\begin{array}{l}\text { Dimeglio } \\
\text { scale }\end{array}$ & 27 \\
\hline $\begin{array}{l}\text { El-Deeb } \\
2007\end{array}$ & 4666 Feet & $\mathrm{Y}$ & $\begin{array}{l}\text { Resis- } \\
\text { tant }\end{array}$ & Idiopathic & 9 months & $\begin{array}{l}\text { TCIL release versus } \\
\text { placebo during surgery for CTEV }\end{array}$ & $\begin{array}{l}\text { Radiog- } \\
\text { raphy, } \\
\text { Dimeglio } \\
\text { scale }\end{array}$ & 28 \\
\hline $\begin{array}{l}\text { Harnett } \\
2011\end{array}$ & 4051 Participants & $\mathrm{Y}$ & $\begin{array}{l}\text { Not } \\
\text { stated }\end{array}$ & Idiopathic & $<90$ days & Ponseti standard versus Ponseti accelerated protocol & Pirani score & 0 \\
\hline $\begin{array}{l}\text { Kaewporn- } \\
\text { sawan } 2007\end{array}$ & 86 128Participants & Y & $\begin{array}{l}\text { Resis- } \\
\text { tant }\end{array}$ & Idiopathic & $\begin{array}{l}5.9 \\
\text { months }\end{array}$ & PMR versus complete subtalar release surgery & Nil & 19.4 \\
\hline Lahoti 2008 & 1326 Feet & $\begin{array}{l}\text { Bilateral } \\
\text { cases only }\end{array}$ & $\begin{array}{l}\text { Resis- } \\
\text { tant }\end{array}$ & $\begin{array}{l}\text { Included } 2 \\
\text { syndromic } \\
\text { feet ( } 1 \text { in } \\
\text { each arm) }\end{array}$ & 10 months & $\begin{array}{l}\text { FHL and FDL lengthening versus } \\
\text { simple decompression in CTEV surgery }\end{array}$ & Pirani score & 48 \\
\hline $\begin{array}{l}\text { Manzone } \\
1999\end{array}$ & 2030 Feet & $\mathrm{Y}$ & Initial & Idiopathic & $\begin{array}{l}7.7 \\
\text { months }\end{array}$ & PMR versus complete subtalar release surgery & nil & 27 \\
\hline Pittner 2008 & 3442 Participants & $\mathrm{Y}$ & Initial & Not stated & 10 days & $\begin{array}{l}\text { Sem-rigid cast versus } \\
\text { plaster of Paris cast with Ponseti technique }\end{array}$ & $\begin{array}{l}\text { Dimeglio } \\
\text { scale }\end{array}$ & 0 \\
\hline Rijal 2010 & 3860 Feet & $\mathrm{N}$ & Initial & Idiopathic & $\begin{array}{l}16.3 \\
\text { months }\end{array}$ & Ponseti versus Kite technique & Pirani score & 0 \\
\hline $\begin{array}{l}\text { Sanghvi } \\
2009\end{array}$ & 4264 Participants & $\mathrm{Y}$ & Initial & Idiopathic & $\begin{array}{l}\leq 9 \\
\text { months }\end{array}$ & Ponseti versus Kite technique & $\begin{array}{l}\text { Radiogra- } \\
\text { phy }\end{array}$ & 36 \\
\hline $\begin{array}{l}\text { Selmani } \\
2012\end{array}$ & 100150Participants & $\mathrm{Y}$ & Initial & Idiopathic & 33 days & Ponseti versus Kite technique & Pirani score & 36 \\
\hline
\end{tabular}




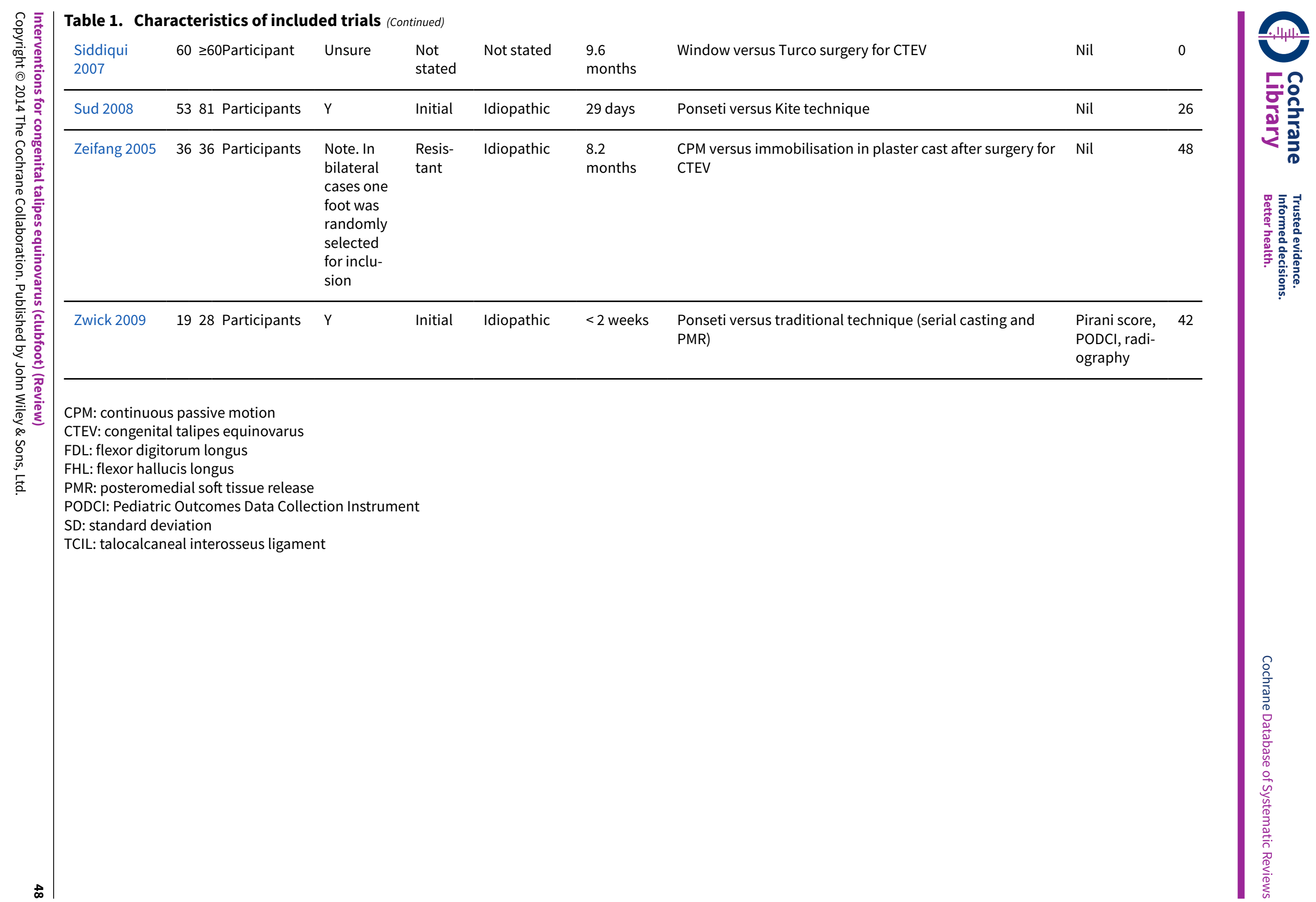




\section{Table 2. Pirani score}

\section{A score is given to each of the following six components}

\begin{tabular}{ll}
\hline Midfoot & Hindfoot \\
\hline Curved lateral border & Posterior crease \\
\hline Medial crease & Rigidity of equinus \\
\hline Talar head coverage & Empty heel \\
\hline Score & \\
\hline 0 & Normal (completely correctable) \\
\hline 0.5 & Moderately normal (partially correctable) \\
\hline 1 & Severely abnormal (not correctable) \\
\hline
\end{tabular}

The total score is between 0 (best) and 6 (worst)

The Pirani score (Pirani 2008). 


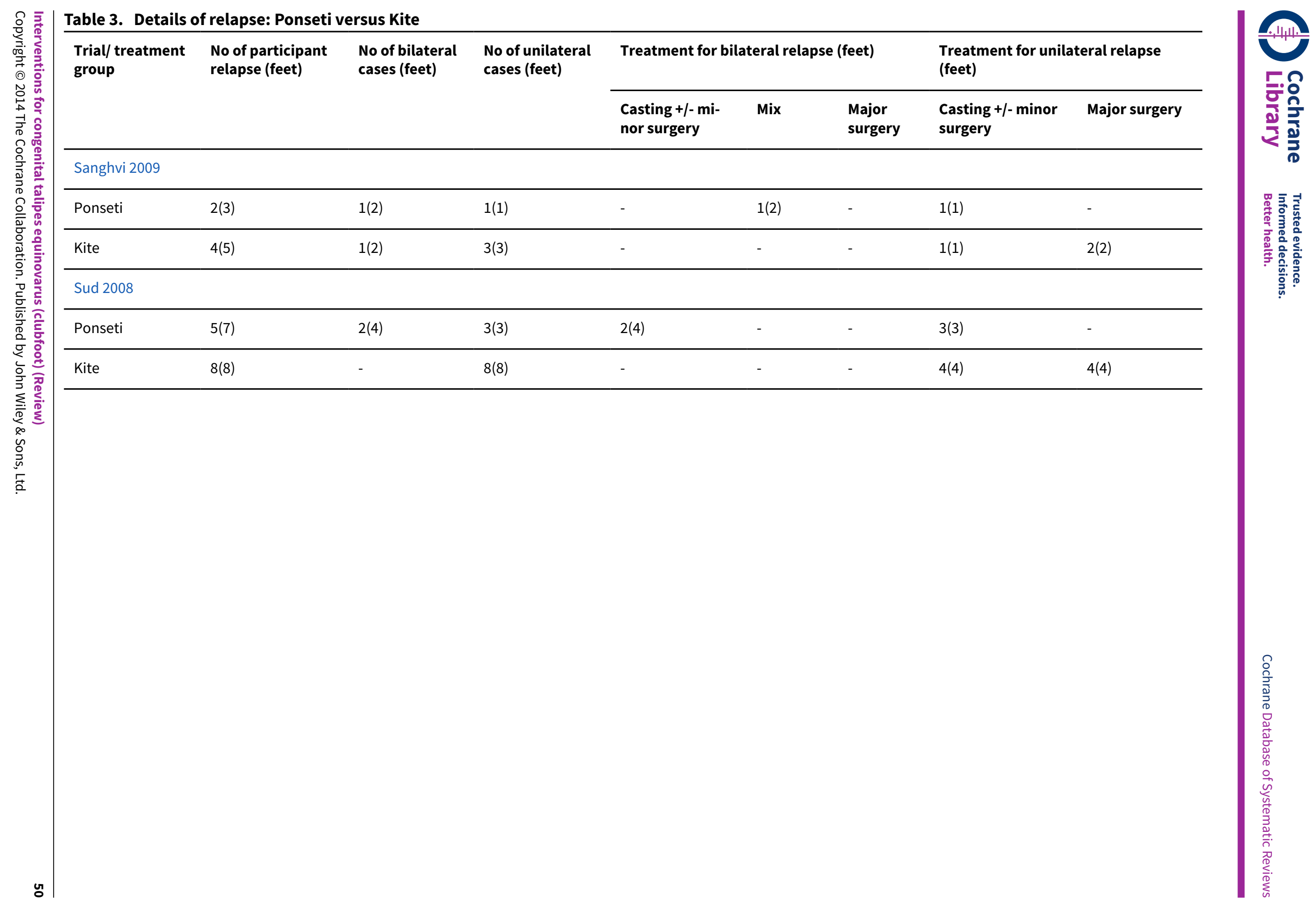


Table 4. Reported details of relapses

\begin{tabular}{|c|c|c|c|c|c|c|}
\hline Study ID & Treatment & $\begin{array}{l}\text { Reported } \\
\text { on relaps- } \\
\text { es }\end{array}$ & $\begin{array}{l}\text { Descrip- } \\
\text { tion of } \\
\text { deformi- } \\
\text { ty with } \\
\text { valid } \\
\text { scales }\end{array}$ & $\begin{array}{l}\text { Group re- } \\
\text { lapses oc- } \\
\text { curred in }\end{array}$ & $\begin{array}{l}\text { Timing of } \\
\text { relapse } \\
\text { reported }\end{array}$ & $\begin{array}{l}\text { Treat- } \\
\text { ment re- } \\
\text { quired } \\
\text { to cor- } \\
\text { rect de- } \\
\text { scribed? }\end{array}$ \\
\hline Cummings 2009 & $\begin{array}{l}\text { Botulinum toxin A versus placebo in } \\
\text { Ponseti treatment }\end{array}$ & Y & $\mathrm{N}$ & $\mathrm{Y}$ & Y & Y \\
\hline El-Deeb 2007 & $\begin{array}{l}\text { TCIL release versus control in CTEV } \\
\text { surgery }\end{array}$ & $\mathrm{Y}$ & $\mathrm{N}$ & $\mathrm{Y}$ & $\mathrm{N}$ & Y \\
\hline Harnett 2011 & $\begin{array}{l}\text { Ponseti standard versus Ponseti accel- } \\
\text { erated protocol }\end{array}$ & Y & $\mathrm{N}$ & $\mathrm{N} / \mathrm{A}$ & $\mathrm{N} / \mathrm{A}$ & $\mathrm{N} / \mathrm{A}$ \\
\hline $\begin{array}{l}\text { Kaewpornsawan } \\
2007\end{array}$ & Modified PMR versus CCSR & $\mathrm{Y}$ & $\mathrm{N}$ & $\mathrm{Y}$ & $\mathrm{N}$ & Y \\
\hline Lahoti 2008 & $\begin{array}{l}\text { FHL and FDL lengthen versus simple de- } \\
\text { compression }\end{array}$ & $\mathrm{Y}$ & $\mathrm{N}$ & $\mathrm{N}$ & $\mathrm{N}$ & $\mathrm{N}$ \\
\hline Manzone 1999 & PMR versus CCSR & $\mathrm{Y}$ & $\mathrm{N}$ & $\mathrm{N}$ & $\mathrm{N}$ & $\mathrm{N}$ \\
\hline Pittner 2008 & $\begin{array}{l}\text { Semi-rigid versus POP for Ponseti treat- } \\
\text { ment }\end{array}$ & \multicolumn{5}{|c|}{ No: follow-up to end of treatment only } \\
\hline Rijal 2010 & Ponseti versus Kite & \multicolumn{5}{|c|}{ No: follow-up to end of treatment only } \\
\hline Sanghvi 2009 & Ponseti versus Kite & $\mathrm{Y}$ & $\mathrm{N}$ & $\mathrm{Y}$ & $\mathrm{N}$ & $\mathrm{Y}$ \\
\hline Selmani 2012 & Ponseti versus Kite & $\mathrm{Y}$ & $\mathrm{N}$ & $\mathrm{Y}$ & $\mathrm{Y}$ & Partial \\
\hline Siddiqui 2007 & Window versus Turco surgery & $\mathrm{Y}$ & $\mathrm{N}$ & $\mathrm{Y}$ & $\mathrm{N}$ & $\mathrm{N}$ \\
\hline Sud 2008 & Ponseti versus Kite & $\mathrm{Y}$ & $\mathrm{Y}$ & $\mathrm{Y}$ & $\mathrm{Y}$ & $\mathrm{Y}$ \\
\hline Zeifang 2005 & $\begin{array}{l}\text { CPM versus immobilisation in a cast af- } \\
\text { ter CTEV surgery }\end{array}$ & $\mathrm{Y}$ & $\mathrm{N}$ & $\mathrm{Y}$ & Y & $\mathrm{N}$ \\
\hline Zwick 2009 & Ponseti versus traditional treatment & $\mathrm{Y}$ & $\mathrm{N}$ & $\mathrm{Y}$ & $\mathrm{Y}$ & $\mathrm{Y}$ \\
\hline
\end{tabular}

CCSR: complete circumferential subtalar release

CPM: continuous passive motion

CTEV: congenital talipes equinovarus

FDL: flexor digitorum longus

FHL: flexor hallucis longus

PMR: posteromedial release

POP: plaster of Paris

TCIL: talocalcaneal interosseus ligament 


\section{APPENDICES}

\section{Appendix 1. CENTRAL and NHSEED search strategy}

\#1(clubfoot or clubfeet or CTEV or talipes)

\section{Appendix 2. MEDLINE OvidSP search strategy}

Database: Ovid MEDLINE(R) <1946 to April Week 3 2013>

Search Strategy:

1 randomized controlled trial.pt. (346797)

2 controlled clinical trial.pt. (85759)

3 randomized.ab. (249438)

4 placebo.ab. (137469)

5 drug therapy.fs. (1603091)

6 randomly.ab. (178468)

7 trial.ab. (257183)

8 groups.ab. (1160728)

9 or/1-8 (2992626)

10 exp animals/ not humans.sh. (3804093)

119 not 10 (2543370)

12 Clubfoot/ (3099)

13 (clubfoot or clubfeet or talipes or ctev).tw. (2326)

1412 or 13 (3773)

1511 and 14 (256)

16 remove duplicates from 15 (254)

\section{Appendix 3. EMBASE OvidSP search strategy}

Database: Embase <1980 to 2013 Week 17>

Search Strategy:

1 crossover-procedure.sh. (36732)

2 double-blind procedure.sh. (114243)

3 single-blind procedure.sh. (17288)

4 randomized controlled trial.sh. (341042)

5 (random\$ or crossover\$ or cross over\$ or placebo $\$$ or (doubl\$ adj blind\$) or allocat\$).tw,ot. (948490)

6 trial.ti. (143998)

7 clinical trial/ (877056)

8 or/1-7 (1554924)

9 (animal/ or nonhuman/ or animal experiment/) and human/ (1255221)

$10 \mathrm{animal} /$ or nonanimal/ or animal experiment/ (3379111)

1110 not 9 (2795799)

128 not 11 (1462587)

13 limit 12 to embase (1139689)

14 clubfoot/ (3621)

15 (clubfoot or clubfeet or talipes or ctev).mp. (4636)

1614 or $15(4636)$

1713 and 16 (107)

18 remove duplicates from 17 (107)

\section{Appendix 4. AMED OvidSP search strategy}

Database: AMED (Allied and Complementary Medicine) <1985 to April 2013>

Search Strategy:

1 Randomized controlled trials/ (1591)

2 Random allocation/ (309)

3 Double blind method/ (473)

4 Single-Blind Method/ (36)

5 exp Clinical Trials/ (3263)

6 (clin\$ adj25 trial\$).tw. (5620)

7 ((singl\$ or doubl\$ or treb\$ or trip\$) adj25 (blind\$ or mask\$ or dummy)).tw. (2314) 
8 placebos/ (527)

9 placebo\$.tw. (2563)

10 random $\$$.tw. (13355)

11 research design/ (1711)

12 Prospective Studies/ (583)

13 meta analysis/ (115)

14 (meta?analys\$ or systematic review\$).tw. (2012)

15 control\$.tw. (28603)

16 (multicenter or multicentre).tw. (762)

17 ((study or studies or design\$) adj25 (factorial or prospective or intervention or crossover or cross-over or quasi-experiment\$)).tw. (10145)

18 or/1-17 (44082)

19 Clubfoot/ (165)

20 (clubfoot or clubfeet or talipes or ctev).tw. (200)

21 (clubfoot or clubfeet or talipes or ctev).mp. (200)

2219 or $20(200)$

2318 and $22(21)$

\section{Appendix 5. CINAHL EBSCOhost search strategy}

Monday, April 29, 2013 10:37:50 AM

S25 S23 AND S24 4

S24 EM 20110315- 295,623

S23 S22 12 [exclude Medline records]

S22 S18 and S21 142

S21 S19 or S20 579

S20 clubfoot or clubfeet or talipes or ctev 579

S19 (MH "Clubfoot") 519

$\mathrm{S} 18 \mathrm{~S} 1$ or S2 or S3 or S4 or S5 or S6 or S7 or S8 or S9 or S10 or S11 or S12 or S13 or S14 or S15 or S16 or S17 602,631

S17 ABAB design* 79

S16 TI random* or AB random* 121,947

S15 ( TI (cross?over or placebo* or control ${ }^{\star}$ or factorial or sham? or dummy) ) or ( AB (cross?over or placebo* or control* or factorial or sham? or dummy) ) 249,438

S14 ( $\mathrm{TI}$ (clin* or intervention* or compar* or experiment* or preventive or therapeutic) or AB (clin* or intervention* or compar* or experiment ${ }^{\star}$ or preventive or therapeutic) ) and ( TI $\left(\right.$ trial $\left.^{\star}\right)$ or AB $\left(\right.$ trial $\left.^{\star}\right)$ ) 85,182

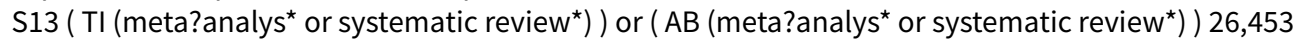

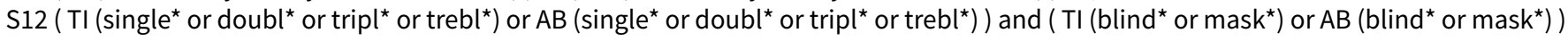
19,578

S11 PT ("clinical trial" or "systematic review") 108,077

S10 (MH "Factorial Design") 866

S9 (MH "Concurrent Prospective Studies") or (MH "Prospective Studies") 203,222

S8 (MH "Meta Analysis") 16,149

S7 (MH "Solomon Four-Group Design") or (MH "Static Group Comparison") 33

S6 (MH "Quasi-Experimental Studies") 5,944

S5 (MH "Placebos") 8,132

S4 (MH "Double-Blind Studies") or (MH "Triple-Blind Studies") 26,479

S3 (MH "Clinical Trials+") 158,969

S2 (MH "Crossover Design") 10,356

S1 (MH "Random Assignment") or (MH "Random Sample") or (MH "Simple Random Sample") or (MH "Stratified Random Sample") or (MH "Systematic Random Sample") 60,710

\section{Appendix 6. PEDro search strategy}

Monday, July 22, 2013

We used a simple search strategy using the following terms:

clubfoot, clubfeet, talipes, ctev (5)

\section{Appendix 7. WHO International Clinical Trials Registry Platform (ICTRP)}

Thursday, July 25, 2013 
We used a simple search strategy using the following terms:

clubfoot, clubfeet, talipes, ctev (21)

\section{Appendix 8. Clinicaltrials.gov search strategy}

Wednesday, November 27, 2013

We used a simple search strategy using the following terms:

clubfoot, clubfeet, ctev (28)

WHAT'S NEW

\begin{tabular}{lll}
\hline Date & Event & Description \\
\hline 21 November 2013 & $\begin{array}{l}\text { New citation required but conclusions } \\
\text { have not changed }\end{array}$ & Updated search incorporated \\
\hline 28 September 2013 & New search has been performed & $\begin{array}{l}\text { One new randomised controlled trial comparing Ponseti and Kite } \\
\text { techniques added. Conclusions are unchanged }\end{array}$ \\
& $\begin{array}{l}\text { Discussion on cost benefit analysis between major surgery and } \\
\text { the Ponseti technique added based on a new identified trial }\end{array}$ \\
\hline
\end{tabular}

\section{CONTRIBUTIONS OF AUTHORS}

KG wrote the first draft with the assistance of JB, PG, DL and VP.

\section{DECLARATIONS OF INTEREST}

JB: research activities are funded by grants and donations from the NHMRC (National Health and Medical Research Council of Australia, Fellowship \#1007569 and Centre of Research Excellence \#1031893), NIH (National Institutes of Neurological Disorders and Stroke and Office of Rare Diseases, \#U54NS065712), Muscular Dystrophy Association, CMT Association of Australia, Foot Power International, Australian Podiatry Education and Research Fund and CMT Association (USA).

PG: No known conflicts of interest.

KG has received funding through the Sydney Medical School, University of Sydney to attend the International Clubfoot Congress in 2011.

DL has received research grants from Novartis, Amgen, Celgene and acted on advisory boards for Lilly and Amgen.

VP: none known.

\section{SOURCES OF SUPPORT}

\section{Internal sources}

- The Children's Hospital at Westmead, NSW, Australia.

- The University of Sydney, NSW, Australia.

\section{External sources}

- No sources of support supplied

\section{DIFFERENCES BETWEEN PROTOCOL AND REVIEW}

The protocol discussed treatments for initial and relapsed CTEV, but a cohort of resistant cases (initial treatment which did not successfully correct the deformity) were identified during this review. Therefore we had to define this additional area in order to differentiate these participants from relapsed cases (i.e. those which had undergone prior treatment with successful outcomes and present with recurrence of deformity). 
The protocol defined outcome measures at a minimum of one year. This was essential as relapse is considered a common occurrence in the treatment of CTEV and defining end of treatment would not have encompassed this outcome. However, once the literature was identified it became apparent that end of treatment foot alignment often significantly affected further treatment. This is highlighted in particular with the identification of resistant cases, which often required significant surgical intervention. Therefore where relevant (for example, at the end of initial treatment), we included results prior to one year.

Treatment for relapse was not a prespecified outcome; however, we noted that it significantly affected further treatment in certain cohorts. Therefore, where data were available, we described the treatment to correct relapse.

A number of trials included data from bilateral (including both right and left feet) and unilateral cases. In bilateral cases, right and left feet from the same subject are unlikely to respond independently. When pooled with unilateral cases, results should be viewed with caution. As this problem became apparent only when we analysed the data, we used statistical methods not defined in the protocol to overcome this bias.

Dr Chris Frost was an additional author in the first published version of the review.

We searched NHSEED, DARE and HTA databases for additional information to use in the Discussion and clinical trials registries for ongoing trials.

\section{INDEX TERMS}

\section{Medical Subject Headings (MeSH)}

Botulinum Toxins, Type A [therapeutic use]; Casts, Surgical; Clubfoot [*therapy]; Decompression, Surgical [methods]; Ligaments, Articular [surgery]; Motion Therapy, Continuous Passive [methods]; Neuromuscular Agents [therapeutic use]; Orthopedic Procedures [methods]; Randomized Controlled Trials as Topic; Recurrence; Treatment Outcome

\section{MeSH check words}

Female; Humans; Infant; Infant, Newborn; Male 